\title{
PANDANGAN RASHĪD RIḌ̂̄ TERHADAP ISRĀILIYĀT DAN ALKITAB DALAM TAFSĪR AL-MANĀR
}

\author{
Muḥammad Akrom Adabi \\ Pesantren Al-Anwar 3 Putra \\ akromadabi@gmail.com \\ Abdullah Mubarok \\ STAI Al-Anwar Sarang-Rembang \\ Broekoly@gmail.com
}

\begin{abstract}
This paper studies on Rashīd Riḍā's view on isräiliyyāt and the Bible in his tafsir alManār. As a reformer in the field of exegesis, Riḍa found urgent necessity in returning al-Qur'an to its original purpose which is to give guidance. The problem is that Riḍa saw many authors of exegesis work (mufassir) before him give profuse and unnecessary exegetical discussion. To Riḍa, displaying this kind of lavish information diverts from the original vision of al-Qur'an and cannot be tolerated. In this case, Riḍa resolutely opposes the quotation of isrāiliyyāt. Interestingly, behind this stance, Riḍa quotes the Bible in his work. This becomes the main focus of this study; how Riḍa views isräiliyyāt and the Bible, what is the essential difference between the two according to Riḍa, and what is the reason behind his quotation of the bible and his opposition against isrāiliyyāt?.

To analyze this topic, descriptive-analytical method is used. The result is, it is found that according to Riḍā, isrāiliyyāt are just unfounded stories and not worth quoting. While the Bible in Rị̂ā's view is a holy book containing the New and Old Testament the truth of which is believed by the People of the Book themselves. In this case, Riḍa believes that the source worth quoting is only one which is șahị and marfü' from the Prophet. Whenever it has to be from the People of the Book, one should quote from the Bible even though Rị̣a himself realizes that there are many oddities in it. There are several reasons behind Riḍā's quoting the Bible (1) Bible is still sourced to the books of Ahl al-Kitab. (2) Bible becomes the guidance of Ahl al-Kitab. (3) Bible can be accounted for according to the Bible.(4) Bible does not have negative motives toward Islam.
\end{abstract}

Key words: Rashīd Rị̣ā, Tafsir al-Manār, isrāiliyyāt, the Bible

Abstrak
Tulisan ini menela'ah pandangan Rashīd Riḍā terhadap isrāiliyyāt dan Alkitab dalam
Tafsir al-Manār. Sebagai seorang pembaharu tafsir, Rị̣ā merasa ada kebutuhan yang
mendesak untuk mengembalikan al-Qur'an sebagaimana diturunkan, yakni sebagai
pemberi petunjuk. Riḍā menemukan ada banyak sekali mufassir pendahulu yang justru
memberikan berbagai macam pembahasan tafsir yang berlebihan.Bagi Riḍā,
menampilkan berbagai macam informasi yang justru menjauhkan visi awal al-Qur'an
adalah hal yang tidak bisa dibenarkan. Dalam hal ini, Riḍā menentang keras pengutipan
isrāiliyyāt. Menariknya, dibalik penolakan itu, Riḍā justru tanpa segan-segan mengutip
Alkitab. Bagaimana pandangan Riḍā terhadap isrāiliyyāt dan Alkitab. Apa esensi

AL-ITQĀN, Volume 2, No. 2, Ag̉ustus 2016145 
perbedaan keduanya menurut Riḍā, serta apa alasan pengutipannya terhadap Alkitab dan penolakannya terhadap isrāiliyyāt menjadi fokus kajian ini.

Dalam menelusuri permasalahan ini, digunakan metode deskriptif analitis. Hasilnya, ditemukan bahwa menurut Riḍa, isrāiliyyāt adalah kisah-kisah yang tidak berdasar yang tidak layak dikutip. Sedangkan Alkitab dalam pandangan Riḍā adalah sebuah kitab suci yang berisi ajaran Injil dan Taurat yang masih diyakini kebenaranya oleh Ahli Kitab itu sendiri. Dalam hal ini, Riḍā meyakini bahwa yang layak dikutip adalah yang șậ̄ḥ marfü' dari Nabi. Kalau pun harus dari Ahli Kitab maka hanya diperbolehkan dengan mengutip dari Alkitab. Ada beberapa alasan yang mendasari pengutipan Alkitab oleh Rị̣ā (1) Alkitab, sumbernya masih Alkitab yang ada pada Ahli Kitab, (2) Alkitab dijadikan pegangan oleh Ahli kitab, (3) Alkitab bisa dipertanggungjawabkan menurut Alkitab, (4) Alkitab tidak memiliki motif negatif terhadap Islam.

Kata kunci : Rashīd Riḍā, Tafsir al-Manār, Isrāiliyyāt, Alkitab

\section{A. Pendahuluan}

Ketika Nabi masih hidup, ada kemudahan bagi para sahabat untuk memahami alQur'an. Mereka dapat dengan mudah langsung menanyakan kepada Nabi saat menemukan kejanggalan. Akan tetapi sepeninggal nabi, detail pemahaman terhadap al-Qur'an tidak bisa mereka rujuk lagi kepada Nabi. Dalam mendalami dan memahami makna al-Qur'an, para sahabat terkadang mencari penjelasan dalam al-Qur'an itu sendiri. ${ }^{1}$ Di samping mereka mencoba mencari penjelasan dari ayat-ayat lain sebagai alat bantu untuk memahami alQur'an, para sahabat juga mencari hadis-hadis Rasulullah. Cara-cara penafsiran dengan hadis seperti ini kemudian dikenal dengan tafsir bi al-ma'thūr. Langkah selanjutnya yang mereka tempuh ialah menanyakannya kepada sahabat yang menyaksikan aṣbāb al-nuzūl ayat. Manakala mereka tidak menemukan jawaban dalam hadis Nabi atau sahabat yang memahami bentuk konteks ayat-ayat tersebut, mereka melakukan ijtihad. ${ }^{2}$

Selain bertanya kepada para sahabat senior sebagai sumber informasi bagi penafsiran al-Qur'an, mereka juga bertanya kepada sahabat-sahabat dari kalangan Ahli Kitab (Yahudi dan Nasrani) yang telah masuk Islam, terutama pada ayat-ayat yang bercerita tentang umatumat terdahulu. Hal itu mereka lakukan lantaran sebagian tema dalam al-Qur'an memiliki persamaan dengan yang ada dalam kitab mereka. ${ }^{3}$

Penafsiran seperti itu terus berkembang sejalan dengan perkembangan pemikiran manusia dan kebutuhannya akan urgensi al-Qur'an sebagai "petunjuk" bagi kehidupan.

\footnotetext{
${ }^{1}$ Muḥammad Ḥusain al-Dhahaby, al-Tafsīr wa al-Mufassirūn (tk: Mus'ab Ibn 'Umayr al-Islāmiyah, 2004 ), hlm. 31.

${ }^{2}$ Ibid., hlm. 45.

${ }^{3}$ Ibid., hlm. 123.
}

146 AL-ITQĀN, Volume 2, No. 2, Ag̉ustus 2016 


\section{Pandangan Rashīd riọā terhadap isrāiliyāt dan .....
Muhammad Akrom Adabi dan Abdullah Mubarok}

Sampai-sampai tanpa disadari bercampurlah hadis-hadis șaḥị̣ dengan isrāiliyyāt. Kehadiran isrāiliyyāt dalam penafsiran al-Qur'an itulah yang menjadi polemik di kalangan para ahli tafsir al-Qur'an. Ada ulama yang setuju dengan masuknya isrāiliyyāt dalam penafsiran, namun tetap dengan seleksi yang ketat, tidak semua isrāiliyyātdapat diterima. Di antara tokoh ini, muncul nama seperti Husein al-Dhahabī. ${ }^{4}$ Hal senada juga diungkapkan oleh Ibnu Taimiyyah dalam bukunya Ușūl al-Tafsìr. ${ }^{5}$

Di sisi lain, ada pula ulama yang tetap enggan menerima kehadiran isrāiliyyāt dalam penafsiran. Bagi mereka, isrāiliyyāt telah memperkeruh khazanah tafsir al-Qur'an. Salah satunya adalah al-Marāghī. Dalam pembukaan tafsirnya, al-Marāghī menyayangkan sikap pengutip isrāiliyyāt. Baginya, pengutip isrāiliyyāt tidak ubahnya seperti pencari kayu di malam hari, yang bukannya mengumpulkan kayu atau emas, tetapi malah mengumpulkan kotoran sebab keruhnya validitas isrāiliyyāt. Pada gilirannya, menurut al-Marāghī, isrāiliyyāt justru mengurangi nilai keilmiahan itu sendiri. ${ }^{6}$

Diantara nama-nama lain, munculah Rashīd Rị̣ā. Sebagai pembaharu tafsir al-Qur'an, Riḍā merasa jenuh dengan sikap para mufassir pendahulu yang terlalu sibuk dengan hal-hal yang justru tafsir tiada berkepentingan dengannya. Rashīd Riḍā dengan tafsir al-Manār-nya menawarkan pandangan-pandangan yang diklaim sebagai bentuk revolusi dalam penafsiran. Sehingga, refilterisasi tafsir menjadi sesuatu yang tidak bisa ditawar lagi untuk mengembalikan tafsir kepada tujuan awal, yakni menjelaskan al-Qur'an. ${ }^{7}$

Tafsir al-Manār merupakan salah satu kitab tafsir populer di kalangan peminat studi al-Qur'an. Tafsir ini dianggap memiliki peranan penting dalam pencerahan pemikiran agama. Tokoh yang berjasa meletakan dasar-dasar dalam tafsir ini adalah Muhammad Abduh yang dikembangkan oleh muridnya, Sayyid MuhammadRashīd Riḍā. Sepakat dengan Abduh, di dalam tafsirnya, Rị̣ā begitu menjauhi isrāiliyyāt, bahkan olehnya, isrāiliyyāt dianggap justru menjauhkan pembaca dari sisi kehidayahan al-Qur'an. ${ }^{8}$

Menariknya dibalik penolakan Rị̣ā terhadap isrāiliyyāt, ia justru mengutip Alkitab yang notabennya bagian dari Ahli kitab. Pengutipan itu sebagai mana yang Rashīd Riḍā

\footnotetext{
${ }^{4}$ Ibid., hlm. 130.

${ }^{5}$ Husain al-Dhahaby, Isrāiliyyāt fì Tafsīr wa al-Hadīth (Kairo : Maktabah Wahbah, t.th), hlm. 53.

${ }^{6}$ Muștafā al-Marāghī, Tafs̄̄r al-Marāghī (Mesir : Shirkah Maktabah Muṣtafā al-Bābī al-Hablī wa Awlāduhu, $1365 \mathrm{H})$, juz 1, hlm. 19.

${ }^{7}$ Rashīd Riḍā, Tafsir al-Manār (Mesir : Hay’ah al-Mișriyah, 1990), juz 5, hlm. 28.

${ }^{8}$ Ibid., hlm. 14.
} 


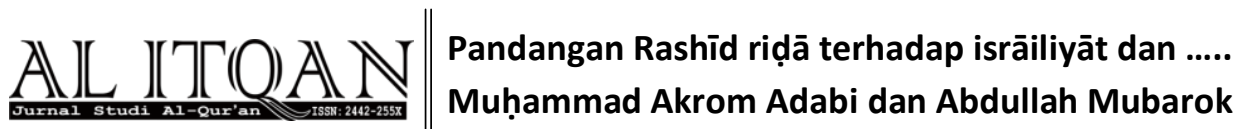

praktikan terhadap Perjanjian Baru ketika menafsirkan surat al-A'rāf ayat 144 mengenai dipilihnya Nabi Musa sebagai utusan. ${ }^{9}$

Maka ada beberapa permasalahan yang hendak dijawab dalam penelitian ini. Pertama, Bagaimana pandangan Rashīd Rị̣ā terhadap isrāiliyyāt dan Alkitab?. Kedua, Apa perbedaan esensi isrāiliyyāt dan Alkitab menurut Rashīd Rị̣ā?. Ketiga, Apa alasan penolakan Rashīd Rị̣ā terhadap isrāiliyyāt dan penerimaannya terhadap Alkitab?

\section{B. Rashīd Riḍā Dan Tafsir al-Manār}

\section{Biografi Rashīd Riḍā}

\section{a. Sekilas Tentang Rashīd Riḍā}

Sayyid Muhammad Rashīd Riḍ̄a adalah salah seorang tokoh pembaharu Islam modern. Nama lengkapnya adalah Muhammad Rashīd bin Ali Riḍā bin Syamsuddīn bin Bahā'uddīn al-Qalmuni al-Ḥusaini. Ia Lahir pada Rabu, 27 Jum'ādil Ulā tahun $1282 \mathrm{H}$, bertepatan dengan 8 Oktober $1865 \mathrm{M}$ di daerah Qalamun, sebelah selatan kota Tripoli Lebanon. Saat itu Lebanon merupakan bagian dari kerajaan Turki Usmani. ${ }^{10}$

Riḍā adalah seorang bangsawan Arab yang mempunyai garis keturunan dari ayah-ibu langsung dari Sayyidina Husain, putra Ali bin Abi Thalib dan Fatimah putri Rasulullah. Oleh karena itu, ia mendapat gelar "sayyid".11 Menurut Shahin, gelar "sayyid" ini memberikan Rị̣ā posisi sosial yang tinggi bagi Rashīd Riḍā dan keluarganya. Sehingga memudahkan baginya untuk menancapkan pengaruh di masyarakat baik dalam bidang sosial, politik maupun agama. $^{12}$

Muhammad Rashīd Riḍā dilahirkan dan dibesarkan dalam lingkungan keluarga terhormat dan taat beragama. Ayahnya adalah seorang terkemuka di

\footnotetext{
${ }^{9}$ Ibid., hlm. 150.

${ }^{10}$ Fahd al-Rūmy, Manhaj al-Madrasah al- 'Aqliyah al-Hadithah fĩ al-Tafsīr (Riyadh : Muassasah al-Risālah, 1983), hlm. 172.

${ }^{11}$ Ibid., hlm. 170.

${ }^{12}$ Emad Eldin Sahin, Modernisasi Bukan Westernisasi, terj. M. Hefni (Yogyakarta: Madani Pustaka Hikmah, 2002), hlm. 11.
} 


\section{Pandangan Rashīd rị̣ā terhadap isrāiliyāt dan .....
Muḥammad Akrom Adabi dan Abdullah Mubarok}

daerah kelahiranya dan juga merupakan seorang imam masjid. ${ }^{13}$ Hal ini kemudian membentuk karakter Riḍā untuk memiliki kepribadian yang positif. ${ }^{14}$

Rashīd Riḍā juga seorang aktivis politik, ia pernah menjabat beberapa posisi penting, diantaranya: sebagai ketua presiden Kongres di Syiria pada tahun 1920 M., anggota delegasi Syiria-Palestina di Jenewa pada tahun 1921 M., anggota Komite Politik Mesir di Kairo selama masa pemberontakan Syiria tahun 1925-1926 M. dan menghadiri Konferensi Islam di Mekkah tahun 1926 M. Pada masa tuanya, meskipun kesehatannya selalui mengalami gangguan, namun ia tidak mau tinggal diam, ia masih aktif dalam menjalankan kegiatannya.

Rashīd Riḍā mengalami kecelakaan ketika dalam perjalanan pulang ke Mesir setelah mengantarkan pangeran Sa'ud al-Faisal dari Suez. Ia wafat pada hari itu juga, Kamis 23 Jumadil Ula 1354 atau 22 Agustus 1935M. Ia dimakamkan di ibu kota Mesir, bersebelahan dengan makam gurunya, Muhammad Abduh. ${ }^{15}$

\section{b. Pendidikan Rashīd Riḍā}

Saat berusia 7 tahun, selain mendapat pengajaran dan asuhan yang religius dari keluarganya, Riḍa juga mulai dimasukan oleh orang tuanya ke taman pendidikan daerah Qalamun yang disebut "al-kuttāb", madrasah yang beraliran Asy’āriyyah. Di sana Rị̣ā juga dikenal memiliki kecerdasan yang menonjol. $^{16}$

Rị̣ā melanjutkan jenjang pendidikannya di sekolah "al-Rashīdiyah". Sekolah ini adalah sekolah dasar negeri. Rashīd Riḍā hanya betah satu setengah tahun untuk sekolah di sini. ${ }^{17}$ Riḍā kemudian berpindah ke madrasah "alWațaniyyah al-Islāmiyyah" yang terletak di Tripoli (Libanon). Sekolah ini merupakan sekolah Islam terbaik pada masa itu. Sekolah nasional Islam ini tidak bertahan lama, karena tidak didukung oleh pemerintah Kerajaan Usmani yang

\footnotetext{
${ }^{13}$ Ayahnya wafat pada bulan Rajab 1323 H, bertepatan dengan 6 September 1905 M. Sedangkan ibunya wafat di Mesir pada Robiul Akhir $1350 \mathrm{H}$ atau 2 September 1931. Lihat: Tāmir Mutawallī, Manhaj Rashīd Riḍ̄a fì al'Aqīdah (Jeddah : Dār al-Maj̄̄id al-'Usayri, 2004), hlm. 61.

${ }^{14}$ Amīr Shakīb Arslan, al-Sayyid Rashīd Riḍ̄a (Kairo : Dār al-Fadhīlah, tt), hlm. 5.

15 Al-Rūmy, Manhaj al-Madrasah., hlm. 182.

${ }^{16}$ Ibid., hlm. 172.

17 Tāmir Mutawallī, Manhaj Rashīd., hlm. 63.
} 


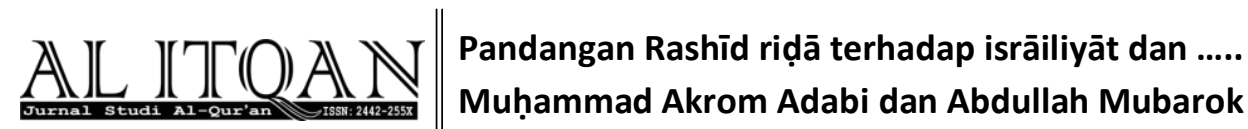

masih berhaluan konservatif. Pada akhirnya sekolah ini pun ditutup. Meski begitu, komunikasi dan kedekatannya dengan para guru dan ulama terus terjalin. Sehingga studi intelektual Riḍa tidak terhenti meski tidak berada pada jalur yang formal lagi. ${ }^{18}$

Rashīd Rị̣ā memiliki pengaruh yang besar dalam pembaharuan. Hal ini dibuktikan dengan sejumlah karya ilmiah yang menyertai gagasan-gagasannya. Sebagian besar karya-karyanya ini dicetak sendiri oleh penerbit Al-Manār, diantara karya-karya tersebut adalah : al-Hikmah al-Shar'iyyah fi Muhakkamāt al-Dādiriyyah wa al-Rifā'iyyah, al-Manār wa al-Azhar, Tārīkh al-Ustādz alImām, Nid̄̄' li al-Jins al-Latīf yawma al-Mawlid al-Nabawī, Dhikra al-Mawlid al-Nabawī, al-Sunnah wa al-Syì'ah, al-Waḥdah al-Islāmiyyah, Haqīqah al-Ribā, Majalah al-Manār, Tafsīr al-Qur'an al-Karīm (al-Manār), Muḥawarāt al-Muslị̣ wa al-Muqlid, al-Wahhabiyyun wa al-Hijāz, Huquq al-Nisā fì al-Islām, al-Imām 'Aly ibn Aby Ṭālib.

\section{Tafsir al-Manār}

Tafsir al-Qur'ān al-Hakīm atau yang biasa dikenal dengan Tafsir al-Manār terdiri dari 12 jilid besar, mulai dari surat al-Fātiḥah sampai surat Yūsuf ayat 53. Tafsir ini hadir sebagai tafsir bi al-ra'yi pada abad modern. Tafsir al-Manār ini, bermula dari pengajian tafsir di Universitas Al-Azhar sejak awal Muharram $1317 \mathrm{H}$. Sebagian pemikiran dalam tafsir ini merupakan sumbangan dari Abduh, melalui pengajian yang diadakan di al-Azhar yang kemudian ditulis oleh muridnya, Rashīd Rị̣ā. Catatan tersebut diserahkan kepada Abduh untuk diperiksa kembali. Setelah melalui revisi, penambahan dan pengurangan, akhirnya naskah tersebut menjadi naskah yang siap dipublikasikan melalui majalah Al-Manār yang sudah terbit terlebih dahulu. ${ }^{19}$

Tafsir al-Manār yang terdiri dari 12 jilid itu lebih wajar untuk dinisbatkan kepada Muhammad Rashīd Riḍā karena di samping ia merupakan penulis utama dan yang mendominasi isinya, orang-orang pun lebih familiar dengan al-Manār Rashīd Riḍā. ${ }^{20}$ Demikian pula dalam penafsiran ayat-ayat yang ditafsirkan oleh gurunya

\footnotetext{
${ }^{18}$ Ibid., 172.

${ }^{19}$ Rị̣ā, Tafsir al-Manār, hlm. 15.

${ }^{20}$ Muhammad al-Ṣibāgh, Lamahāt fì Ulūm al-Qur'ān wa Ittijāhāt al-Tafsīr (Beirut: al-Maktab al-Islāmī, 1990), hlm. 320 .
} 


\section{Pandangan Rashīd riḍā terhadap isrāiliyāt dan .....
Muhammad Akrom Adabi dan Abdullah Mubarok}

dalam pengajian awal, bisa ditemukan pula pendapat-pendapat Rashīd Riḍā. Jadi, di dalam al-Manār bagian awal, selain menuliskan penafsiran gurunya, Riḍā juga membubuhi dengan pandangan serta tambahannya sendiri. Ia membedakan وأقول"، "وأنا أقول"، " keterangan dari gurunya dan keterangan darinya sendiri dengan "sebelum menguraikan pendapatnya. ${ }^{21}$

Tujuan utama dari tafsir menurut Riḍā adalah menjabarkann apa yang dikandung oleh al-Qur'an untuk mengantar umat menuju pada kebahagiaan dunia dan akhirat. ${ }^{22}$ Visi inilah yang juga dikembangkan oleh Rashīd Rị̣ā dalam tafsirnya. Dengan menekankan fungsi-fungsi kehidayahan al-Qur'an untuk pembaca, agar mereka benar-benar dapat menjalani kehidupan ini di bawah bimbingan dan petunjuk al-Qur'an. $^{23}$

\section{Isrāiliyyāat Dan Alkitab}

\section{Isrāiliyyāt}

Ditinjau dari etimologi, kata “isrāiliyyāat” (الإسرائيليات) adalah bentuk jama' dari isrāīliyyāhh (الإسرائيلية) yakni bentuk kata yang dinisbatkan pada kata Israil yang berasal dari bahasa Ibrani, "Isra" yang berarti hambadan " $i l$ " yang bermakna Tuhan. ${ }^{24}$ Sedangkan menurut istilah, yang dimaksud dengan isrāiliyyāt adalah kisah-kisah yang dinukil melalui jalur periwayatan Ahli Kitab, khususnya Yahudi. ${ }^{25}$ Meskipun demikian, Isrāiliyyāt juga mencakup Nasrani karena memang, kaum Nasrani juga turut ambil bagian dalam konstelasi penafsiran isrāiliyyāt. Hanya saja kaum Yahudi lebih dominan dalam penyebaran isrāiliyyāt. ${ }^{26}$ Sehingga, narasumber utama dalam isrāiliyyātadalah Yahudi dan Nasrani. Hal ini perlu dipertegas. Sebab, dalam proses

\footnotetext{
${ }^{21}$ Riḍā, Tafsīr al-Manār, hlm. 15.

${ }^{22}$ Al-Ṣibāgh, Lamahāt., hlm. 322.

${ }^{23}$ Riḍā, Tafsīr al-Manār, hlm. 8.

${ }^{24}$ Dari segi historis, Isrāīl berkaitan dengan Nabi Ya'qūb bin Ishāa bin Ibrāhīm, dimana keturunan beliau yang berjumlah dua belas yang disebut dengan Banî Isrâil. Lihat: Dhahaby, Isrāiliyyāt fi al-Tafsīr., hlm. 13.

${ }^{25}$ Lihat:Arsip catatan hasil Muktamar Islam Internasional mengenai "Metode Pakar Tafsir dan Penyarah Hadis" tahun 2006 di International Islamic University Malaysia, hlm. 36.

${ }^{26}$ Al-Dhahaby, Isrāiliyyāt fi al-Tafsīr, hlm. 13.
} 


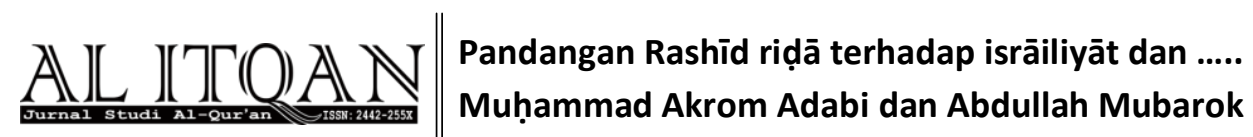

penyebarannya, orang-orang non-Ahli Kitab seperti kalangan sebagian kecil sahabat dan tabi' in juga berperan sebagai sumber sekunder.

Pada fase selanjutnya, formulasi tentang isrāiliyyāt terus berkembang. Isrāiliyyāt mencakup informasi-informasi yang tidak ada dasarnya sama sekali dalam buku-buku catatan kuno. Isrāiliyyāt menjadi istilah untuk kisah palsu yang dilancarkan oleh non muslim yang diselundupkan pada tafsir dan hadis. Cerita itu seperti kisah pernikahan Rasulullah dengan Zainab. ${ }^{27}$ Jadi, isrāiliyyāt merupakan sesuatu yang meresap ke dalam tafsir dan hadis di mana periwayatnya berkaitan dengan Yahudi dan Nasrani, baik yang disampaikan tersebut menyangkut agama mereka atau tidak.

Dari penjelasan di atas pula, isrāiliyyāt memiliki beberapa ciri-ciri. Pertama, berita-berita yang sumber utama atau primernya adalah perawi yang berasal dari Ahli Kitab baik Yahudi ataupun Nasrani. Kedua, berita yang sumbernya berasal dari rawi sahabat atau tabi'in atau pengikut tabi'in yang terkenal sering menerima riwayat dari Ahli Kitab dan sedang mengisahkan kisah terdahulu. Posisi periwayat ini hanya sebagai sumber kedua atau skunder di mana sumber utamanya tetap Yahudi ataupun Nasrani. Ketiga, sanad-nya tidak sampai kepada nabi Muhammad.

\section{Alkitab}

Kata "Alkitab" secara etimologi berasal dari bahasa Arab, "Al" dan "Kitab", yang secara harfiah berarti "kitab (tersebut)" atau "buku (itu)", di mana kata "Al" merupakan kata sandang dalam bahasa Arab yang menunjukan sesuatu yang diketahui. Sehingga sebenarnya istilah "Alkitab" sendiri dapat juga merujuk kepada kitab suci agama Islam, Al-Qur'an. Sedangkan dalam Kamus Besar Bahasa Indonesia disebutkan bahwa Alkitab merupakan sebutan untuk kitab suci umat Kristiani (atau biasa disebut dengan Bible). Alkitab dibagi atas dua bagian utama: Perjanjian Lama (Old Testament) dan Perjanjian Baru (New Testament). ${ }^{28}$ Alkitab untuk saat ini merupakan landasan utama dalam keberagamaan orang Yahudi dan Kristen. $^{29}$

\footnotetext{
${ }^{27}$ Ibid., hlm. 13.

${ }^{28}$ Dendy Sugono, dkk, Kamus Besar Bahasa Indonesia (Jakarta: Pusat Bahasa, 2008), hlm. 44.

${ }^{29}$ Michael Keene, Alkitab, Sejarah, Proses Dan Pengaruhnya, Terj. Y Dwi Koratno (Yogyakarta: Kanisius, 2006), hlm. 6.
} 


\section{Pandangan Rashīd riọā terhadap isrāiliyāt dan .....
Muhammad Akrom Adabi dan Abdullah Mubarok}

Perjanjian Lama merupakan kitab suci yang didominasi oleh Taurat, kitab suci orang Yahudi. Orang Yahudi memiliki kultur keagaman tersendiri, begitu pula dengan Kristen. ${ }^{30}$ Orang Yahudi berpegang pada Taurat sebagaimana disebut dalam surat al-Māidah (4) ayat 44:

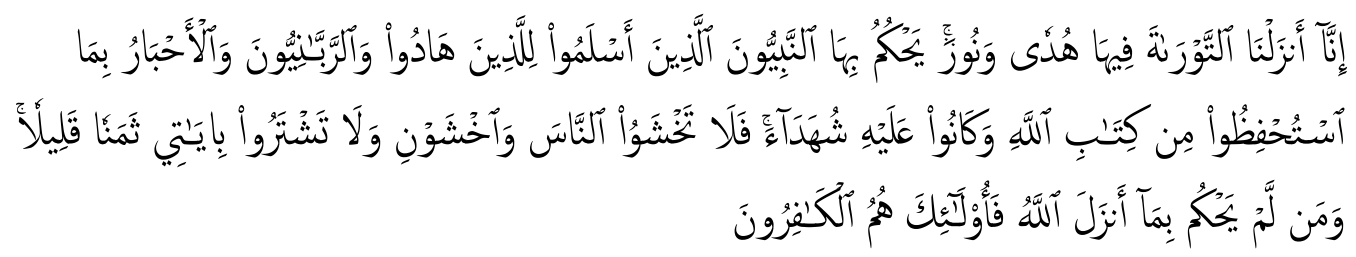

Sesungguhnya Kami telah menurunkan Kitab Taurat di dalamnya (ada) petunjuk dan cahaya (yang menerangi), yang dengan Kitab itu diputuskan perkara orangorang Yahudi oleh nabi-nabi yang menyerah diri kepada Allah, oleh orang-orang alim mereka dan pendeta-pendeta mereka, disebabkan mereka diperintahkan memelihara kitab-kitab Allah dan mereka menjadi saksi terhadapnya. Karena itu janganlah kamu takut kepada manusia, (tetapi) takutlah kepada-Ku. Dan janganlah kamu menukar ayat-ayat-Ku dengan harga yang sedikit. Barangsiapa yang tidak memutuskan menurut apa yang diturunkan Allah, maka mereka itu adalah orang-orang yang kafir. (QS. al-Māidah (4) ayat 44 )

Istilah Taurat ini juga digunakan untuk menyebut kitab yang diturunkan kepada Nabi Musa. Untuk saat ini, kitab tersebut biasa dikenal dengan Perjanjian Lama yang di dalamnya juga memuat Zabur dan beberapa lampiran-lampiran lain yang mereka gunakan sebagai pegangan. ${ }^{31}$

Sedangkan Perjanjian Baru adalah sebutan untuk Injil. ${ }^{32}$ Pada perkembangannya, Injil juga digunakan umat Nasrani untuk menyebut empat kitab lain, yaitu Injil Matius, Injil Markus, Injil Lukas dan Injil Yohanes, ${ }^{33}$ di dalamnya juga memuat kisah para utusan (Hawary), Surat Paulus, Surat Yohanes, Surat Yudas dan wahyu-wahyu Yohanes. ${ }^{34}$ Injil yang asli sendiri adalah sebuah kitab yang diturunkan kepada nabi Isa. Al-Qur'an telah menegaskan hal ini.

\footnotetext{
${ }^{30}$ Kedua kultur ini juga memberi sedikit kontribusi pada mausknya Isrāiliyyāt dalam Al-Qur'an, karena memang salah satu sumber rujukan para narasumber Isrāiliyyāt adalah Alkitab itu sendiri. Lihat: al-Dhahabī, al-Tafsīr wa al-Mufassirūn, hlm. 121.

${ }^{31}$ Al-Dhahabī, al-Tafsīr wa al-Mufassirūn, hlm. 121.

${ }^{32}$ Namun, sejatinya injil merupakan bagian kecil dari Alkitab secara keseluruhan. Karena, sebagaimana yang dijelaskan oleh Rashīd Rị̣ā sendiri, yang disebut sebagai kitab-kitab Injil itu hanyalah empat kitab pertama dalam bagian Perjanjian Baru. Lihat: Rị̣ā, Tafsīr al-Manār, juz 3, hlm. 129.

${ }^{33}$ Keempat kitab ini membahas tentang perjalanan Nabi Isa, sejarah serta perjalanan keilmuannya. Oleh sebab itulah kitab ini disebut Injil. Lihat: Ibid., juz. 3, hlm. 131.

${ }^{34}$ Ibid., juz. 3, hlm. 131.
} 


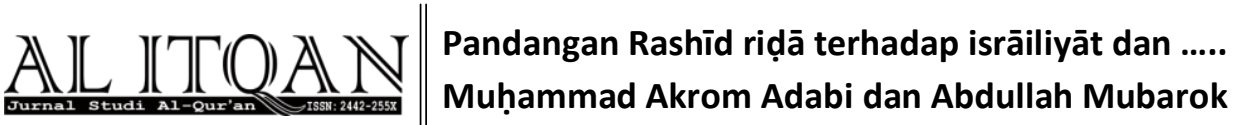

Pembahasan Alkitab disini akan fokus pada penggunaan kata Alkitab yang berarti kitab suci umat Kristiani yang berisi Perjanjian Lama dan Perjanjian Baru. Alkitab secara keseluruhan terdiri dari 66 kitab yang oleh umat Kristiani, kesemuanya diyakini sebagai wahyu Tuhan. ${ }^{35}$

\section{Rashīd Riḍā dan Isrāiliyyā̄t}

\section{Isrāiliyyāt dalam PandanganRashīd Riḍā}

Sebagai seorang pembaharu tafsir, Rị̣ā merasa ada kebutuhan yang mendesak untuk mengembalikan al-Qur'an sebagaimana diturunkan, yakni sebagai pemberi petunjuk. Hal ini merupakan motivasi utama yang mendorong Rashīd Riḍā untuk menulis tafsir al-Qur'an. Riḍā menemukan ada banyak sekali mufasir pendahulu yang justru memberikan berbagai macam pembahasan tafsir yang berlebihan. ${ }^{36}$ Hal ini menurutnya akan menghilangkan visi awal al-Qur'an sebagai petunjuk. Karena menurutnya, penjelasan yang tidak ada relevansi dengan ibrah alQur'an justru akan menjauhkan para pembaca dari ibrah kandungan utama dan kehidayahan al-Qur'an itu sendiri. Bagi Riḍā, menampilkan berbagai macam informasi yang justru menjauhkan visi awal al-Qur'an adalah hal yang tidak dibenarkan. ${ }^{37}$ Sikap ini bisa dilihat dalam ungkapan yang dipaparkan Rashīd Riḍā dalam pembukaan buku tafsirnya.

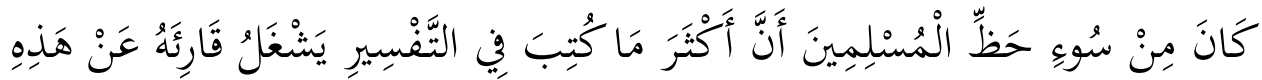

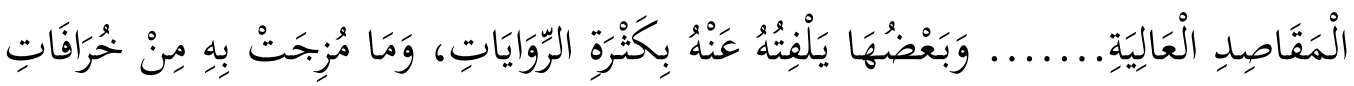

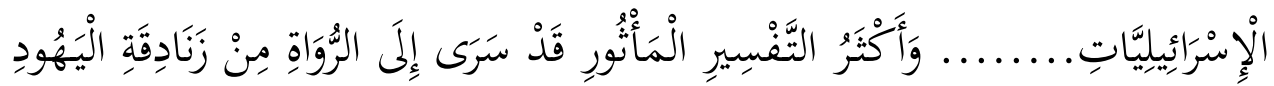

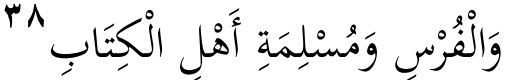

Sialnya kebanyakan apa yang ditulis dalam tafsir itu justru membuat pembaca lupa dari tujuan mulia al-Qur'an (petunjuk) ..... Ada juga yang memasukkan banyak sekali isrāiliyyātserta berbagi kisah yang bercampur dengan kurafat isrāiliyyāt ..... Kebanyakan tafsir riwayat memang memberlakukan para perawi dari golongan zindiq Yahudi, Persia dan Ahli Kitab yang telah masuk Islam.

\footnotetext{
${ }^{35}$ Usman, “Memahami Israiliyat dalam Penafsiran al-Qur’an”, dalam Jurnal Ulumuna, Vol. 5, No. 2, hlm. 299.

36 Dalam bukunya, Riḍā beberapa kali menyebutkan nama-nama mufasir yang dengan ceroboh menukil Isrāiliyyāt tanpa adanya filter terlebih dahulu. Diantara nama-nama yang kadang disebut itu adalah Ibnu Kathir, al-Suyuti dan al-Baghawy. Lihat: Rị̣ā, Tafsīr al-Manār, juz 1, hlm. 147.

${ }^{37}$ Ibid., juz 1, hlm. 10.

${ }^{38}$ Ibid., juz 1, hlm. 8.
} 


\section{Pandangan Rashīd riọā terhadap isrāiliyāt dan .....
Muḥammad Akrom Adabi dan Abdullah Mubarok}

Riḍā menghimbau agar ketidak-pentingan isrāiliyyātini jangan diperbesar lagi. Memperlebar pembahasan isrāiliyyāt hanya akan membuang waktu. Sebab menurutnya di dalamnya ada banyak sekali lelucon yang jelas tidak layak untuk ditampilkan. ${ }^{39}$ Isrāiliyyāt hanyalah Informasi yang tidak mencapai derajat ajaran yang layak untuk diikuti sebab isrāiliyyāt hanyalah kisah yang tidak jelas siapa pengkabarnya. $^{40}$

Riḍā menegaskan bahwa isrāiliyyāt adalah penafsiran Ahli Kitab yang dibuat-buat untuk menipu umat Islam dan membuat mereka lupa akan kitab aslinya agar mereka merujuk pada Ahli Kitab. Selain itu, hal ini juga mereka buat untuk menunjukkan betapa mereka memiliki kedekatan yang lebih dengan Allah dan mereka memiliki posisi yang istimewa diantara kaum kaum yang lain. ${ }^{41}$

Sikap ini benar-benar diaktualisasikan oleh Rashīd Riḍā dalam menolak isrāiliyyāt. Dalam satu kesempatan ditemukan sebuah riwayat yang sebenarnya masih tercantum dalam Șaḥị̣ Bukhari dan Muslim divonis oleh Rị̣ā sebagai isrāiliyyāt sebab ada beberapa indikasi yang mengarah pada kesimpulan demikian. Seperti saat Riḍā mengkritik keras berbagai riwayat mengenai Dajjal dan Jassasah. ${ }^{42}$

Menurut Riḍā meskipun status riwayat tersebut șahịị, namun tidak ada satupun yang mencapai derajat marfū'. Riḍa juga memperkuat pendapatnya ini dengan mengutip Ibnu Ḥajar yang mencoba mengkritiknya dari segi pendekatan ilmu hadis, perbedaan matan serta isinya yang bertentangan dan berbagai kritikan lain. Dari kecacatan tersebutlah maka Riḍa memvonis bahwa riwayat tersebut adalah isrāiliyyāt. ${ }^{43}$ Menurut hemat penulis, vonis Rị̣ā di atas adalah sebuah prinsip yang dibangun oleh Rị̣ā dalam menyeleksi sebuah riwayat. Bukan berarti jika riwayat sudah ada dalam kitab hadis yang dianggap paling șaḥị̣ sekalipun berarti riwayat tersebut benar dan bukan isrāiliyyāt.

Fakta ini semakin menunjukkan betapa seriusnya Rashīd Riḍā dalam menyaring isrāiliyyāt bahkan untuk sebuah informasi yang ada sumber dalam kitab

\footnotetext{
${ }^{39}$ Ibid., juz 12, hlm. 64.

${ }^{40}$ Ibid., juz 7, hlm. 4.

${ }^{41}$ Ibid., juz 3, hlm. 241.

${ }^{42}$ Ibid., juz 9, hlm. 415.

${ }^{43}$ Ibid.
} 


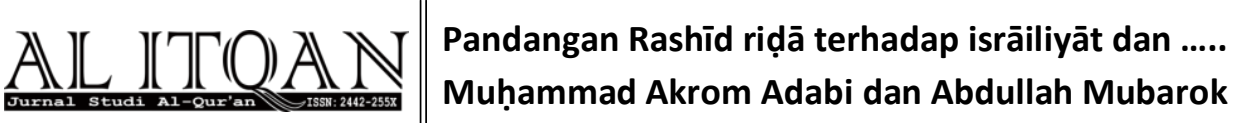

hadis terpercaya. Jika di dalamnya ada indikasi isrāiliyyāt maka Rị̣ā tidak segansegan untuk mengkritiknya. Hal ini secara tersirat juga memunculkan beberapa fakta. Pertama, Riḍā tidak segan mengkritik hadis jika isinya memang diindikasi ada susupan isrāiliyyāt. Kedua, bagi Riḍā, hadis sahabat yang pada tataran tertentu bernilai marfū', yakni pada bagian lā majāla fìhi lil ijtihād perlu dikoreksi lagi. Pasalnya, tidak menutup kemungkinan mereka mendapatkan sumber dari Yahudi yang memiliki motif terselubung. Ketiga, penafsiran sahabat tidak bernilai mutlak benar dan berkedudukan beda dengan penafsiran nabi Muhammad.

\section{Alasan Penolakan Riḍā terhadap Isrāiliyyāt}

Sikap Rashīd Rị̣ā yang berlebihan dalam menolak isrāiliyyāt itu bukannya tanpa alasan.Ada beberapa alasan yang disampaikan oleh Rashīd Riḍā dalam bukunya.Hal ini selain menggambarkan prespektif isrāiliyyāt menurut Rashīd Riḍā, juga menggambarkan alasan penolakannya terhadap isrāiliyyāt. Berikut beberapa alasan penolakan Rashīd Riḍā :

\section{a. Posisi Isrāiliyyāt}

Riḍā merasa jenuh karena isrāiliyyāt banyak menampilkan kisah-kisah yang tidak penting dan tidak berpengaruh pula terhadap esensi ibrah yang terkandung dalam suatu ayat. Lebih daripada itu, isrāiliyyāt menurutnya bahkan mengalihkan pembaca untuk mendapatkan petunjuk yang semestinya itu menjadi tujuan awal al-Qur'an diturunkan. Masuknya. isrāiliyyāt telah mendistorsi pemahaman terhadap al-Qur'an dan ajaran Islam. ${ }^{44}$

Menurut Rị̣ā, riwayat-riwayat isrāiliyyāt ini tidak pantas untuk digunakan sebagai tafsir kalam Allah yang mulia.Isrāiliyyāt telah menipu dan mengecoh para mufassir.

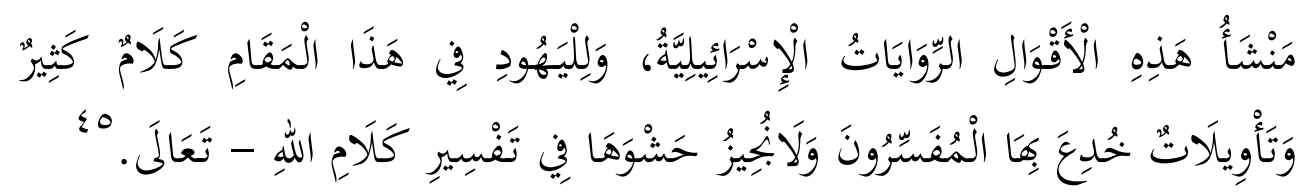

Sumber kemunculan pendapat-pendapat ini adalah riwayat Isräiliyyāt. Dalam konteks ini orang Yahudi memiliki wadah informasi yang banyak serta berbagai

\footnotetext{
${ }^{44}$ Ibid., juz 3, hlm. 241.

${ }^{45}$ Ibid., juz 1, hlm. 269.
} 


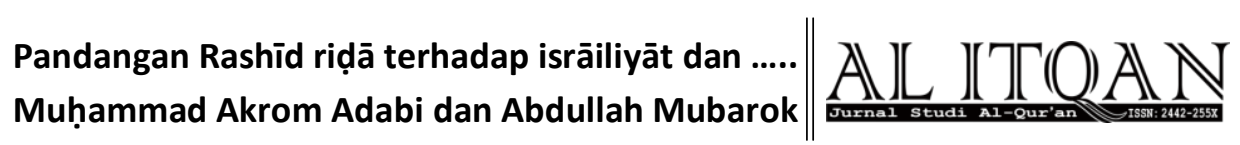
penakwilan yang mengecoh para mufassir.Kami kira hal itu tidak layak digunakan untuk menafsiri kalamullah.

\section{b. Motif di Balik Isrāiliyyāt}

Riḍā mengajak para pembaca untuk tidak terlalu larut dalam isrāiliyyāt serta berhati-hati dengan berbagai macam kisah tersebut. Menurutnya, kebanyakan merupakan susupan dari musuh Islam agar umat Islam lalai terhadap agamanya sendiri. Artinya ada motif terselubung dari berkembangnya isrāiliyyāt di kalangan umat Islam. Hal ini menurutnya perlu diwaspadai. Hal ini ditegaskan sendiri oleh Riḍā :

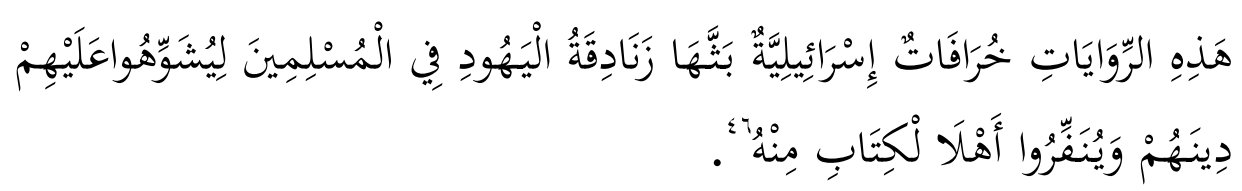

Cerita-cerita ini merupakan tahayul isräiliyyāt yang disusupkan oleh orang Yahudi zindiq terhadap kaum muslimin mereka melupakan agama mereka sendiri dan beralih ke Ahli Kitab.

\section{c. Status Narasumber}

Keabsahan seorang tokoh dalam sumber berita merupakan hal penting yang harus dikaji. Jika tokoh tersebut terkena stigma negatif maka riwayatriwayatnya tertolak. Dalam masalah ini narasumber utama isrāiliyyāt akan disoalkan oleh Rashīd Riḍā. Pasalnya, banyak ulama yang setuju dan menganggap mereka adalah tokoh-tokoh yang bisa diterima riwayatnya, sementara Rị̣ā menganggap bahwa mereka sebenarnya tertipu oleh para tokoh tersebut.

Dalam al-Manār, Riḍā sering menggeneralisir kenegatifan isrāiliyyāt baik dari segi isi maupun narasumber. Keterangan ini bisa dilihat dari berbagai komentar-komentarnya terhadap para tokoh isräiliyyāt. Salah satunya adalah sebagai berikut:

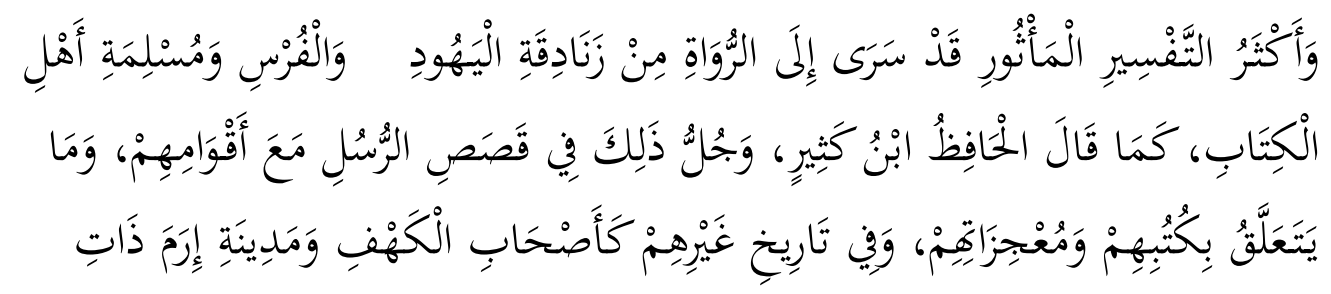

\footnotetext{
${ }^{46}$ Ibid., juz 1, hlm. 384.
} 


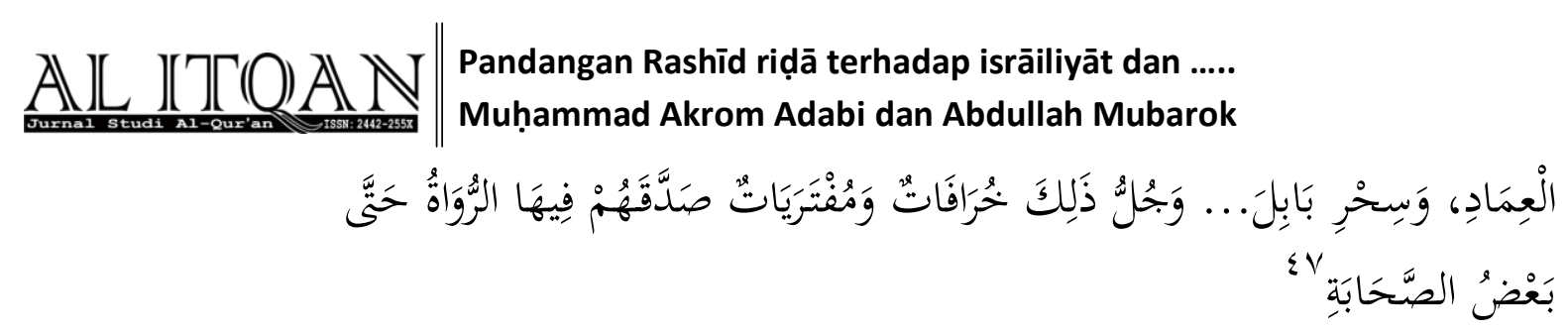

Kebanyakan tafsir riwayat memang memberlakukan para rawi dari Ahli Kitab zindiq,orang-orang Persia serta Ahli Kitab yang telah masuk Islam sebagaimana yang disampaikan oleh Ibnu Katsir.Kebanyakan mengenai kisah para rasul dan kaum kaumnya juga mengenai kisah yang berhubungan dengan kitab dan mukjizat para rasul serta berbagai cerita sejarah seperti Ashabul Kahfi, Kota Aram, sihir Babil... Sebagian besar dari informasi diatas adalah khurafat dan tahayul-tahayul yang dibenarkan oleh para perawi termasuk sahabat.

Selain ungkapan di atas, pernyataan "cap" negatif tersebut juga dilancarkan pada beberapa tokoh utama isräiliyyāt yang oleh kebanyakan ulama dianggap adil. ${ }^{48}$ Riḍā menjelaskan dalam bukunya bahwa para tokoh-tokohjarh wa ta'dil telah tertipu dengan menganggap adil tokoh isrāiliyyāt seperti Ka'b alAkhbār, Tamīm al-Dāri, Abdullāh bin Salam, Wahb bin Munabbih sampai yang tabiīn seperti Ibnu Juraij. ${ }^{49}$ Menurutnya, andaikan mereka mengetahui apa yang Riḍā ketahui tentang track record tokoh-tokoh tersebut, tentu mereka akan berpendapat lain. ${ }^{50}$ Dalam masalah tokoh ini, hanya ada satu tokoh yang diakui kealimannya oleh Riḍā yaitu Abdullah Bin Salam. Riḍā mengakui bahwa Abdullah Bin Salam adalah seorang ulama. ${ }^{51}$

Selain Ka'b dan Wahb bin Munabbih, ada juga tokoh lain yang mendapat cap negatif dari Rị̣ā. Dia adalah Ibnu Juraij seorang penulis buku serta salah seorang ulama yang terkenal sebagai pengumpul hadis pertama.Menurut Riḍā Ibnu Juraij tidak memiliki kapasitas yang memadai. Bahkan Rị̣ā memvonis Ibnu Juraij sebagai orang yang gemar menyembunyikan hadis. ${ }^{52}$

\footnotetext{
${ }^{47}$ Ibid., juz 1, hlm. 8.

${ }^{48}$ Salah satu ulama tersebut adalah ad-Dahabi.Dalam bukunya Dzahabi menjabarkan tokoh-tokoh tersebut secara ringkas dan padat. Dhahaby menjabarkan status tokoh-tokoh tersebut serta berbagai tuduhan yang dilancarkan pada mereka.Namun pada akhirnya Dhahaby berkesimpulan bahwa mereka adalah tokoh Adil yang bisa dipertanggungjawabkan. Lihat: al-Dhahaby, al-Tafsìr wa al-Mufassirūn., juz 1, hlm. 130; al-Dhahaby, Isrāiliyyāt., hlm. 71.

49 Khusus untuk Ibnu Juraij, al-Dhahaby menyarankan kepada pembaca untuk selektif dalam menerima riwayatnya.Pasalnya, dalam menulis Hadis Ibnu Jurayj tidak menulis hadis yang șaḥị̣ saja melainkan semua hadis yang diketahuinya. Lihat: Dhahaby, al-Tafsìr wa al-Mufassirūn., juz 1, hlm. 44.

${ }^{50}$ Riḍā, Tafsir al-Manār., juz 8, hl. 399 dan juz 1, hlm. 147.

${ }^{51}$ Ibid., juz 2, hlm. 17.

${ }^{52}$ Ibid., juz 9, hlm. 308.
} 


\section{Pandangan Rashīd riọā terhadap isrāiliyāt dan .....
Muhammad Akrom Adabi dan Abdullah Mubarok}

Mengenai Tamīm al-Dāri penulis belum menemukan secara spesifik kritikan Rị̣ā terhadapnya, akan tetapi ditemukan kutipan informasi dari Tamīm dalam al-Manār yakni pada Juz 7 halaman 9 tentang kisah Tamim yang berkata pada nabi mengenai kesegaran Arak atau pada al-Manār Juz 7 halaman 181 tentang keterangan lanjutan pada suatu ayat.

\section{Implementasi Isräiliyyāt dalam Tafsir al-Manār}

Dalam al-Manār, ditemukan beberapa pengutipan isrāiliyyāt. Sebagian besar diantaranya sengaja dikutip oleh Rashīd Riḍā guna menunjukkan betapa isrāiliyyāt tidak bisa dibenarkan. Dalam melakukan penelusuran data ini, dilakukanlah pengumpulan kutipan isrāiliyyāt dalam surat al-Baqarah dan ditemukan tujuh tempat pengutipan isrāiliyyāt. Berikut hasil temuannya :

\begin{tabular}{|c|c|c|c|c|}
\hline No. & Kutipan & $\begin{array}{c}\text { Surat: } \\
\text { ayat } \\
\text { Juz: hal }\end{array}$ & Status & Tema \\
\hline 1. & 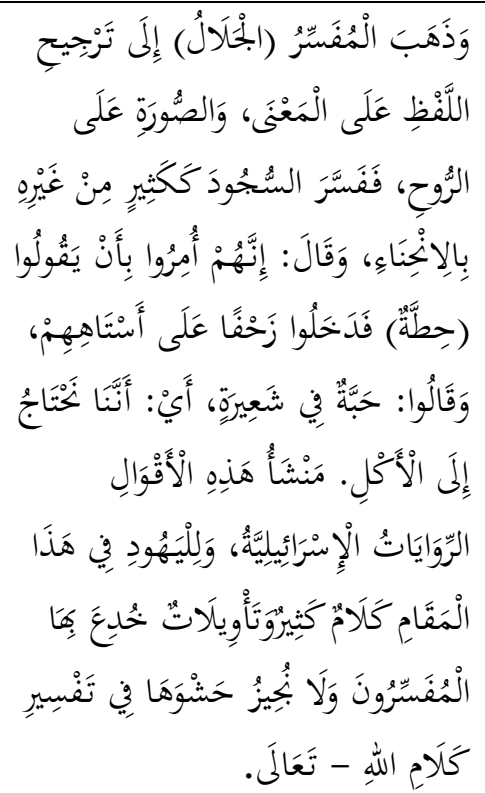 & $\begin{array}{c}\text { Al-Baqarah } \\
59 \\
1: 269\end{array}$ & $\begin{array}{c}\text { Meski informasi } \\
\text { ini juga ada di } \\
\text { kitab șahīḥ akan } \\
\text { tetapi riwayat ini } \\
\text { divonis Rị̣ā } \\
\text { sebagai } \\
\text { isrāiliyyāt } \\
\text { karena ada } \\
\text { beberapa faktor }\end{array}$ & $\begin{array}{l}\text { Mengenai kisah } \\
\text { bani isrāiliyyāt }\end{array}$ \\
\hline 2. & 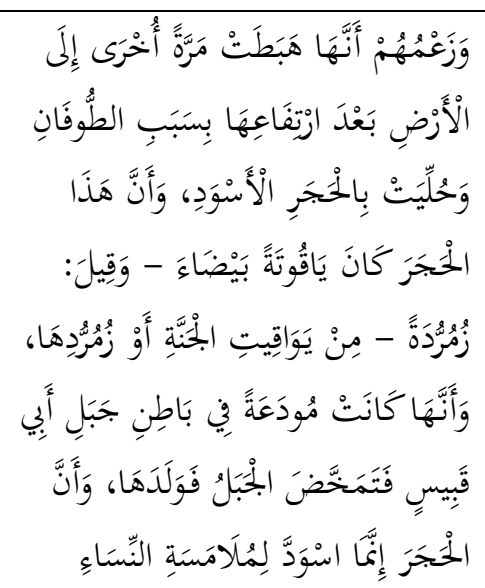 & $\begin{array}{c}\text { Al-Baqarah } \\
127 \\
1: 384\end{array}$ & $\begin{array}{c}\text { Disalahkan, } \\
\text { riwayat ini } \\
\text { adalah khurafat } \\
\text { isrāiliyyyāt }\end{array}$ & $\begin{array}{c}\text { Mengenai asal } \\
\text { usul Hajar Aswad }\end{array}$ \\
\hline
\end{tabular}




\begin{tabular}{|c|c|c|c|c|}
\hline No. & Kutipan & $\begin{array}{l}\text { Surat: } \\
\text { ayat } \\
\text { Juz: hal }\end{array}$ & Status & Tema \\
\hline & 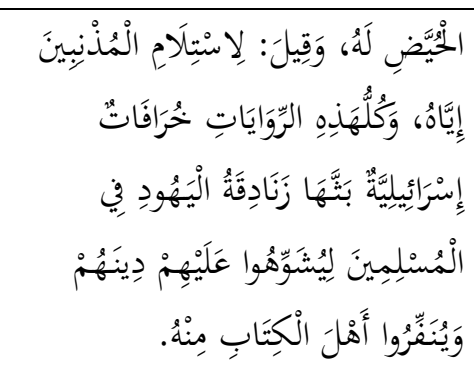 & & & \\
\hline 3. & 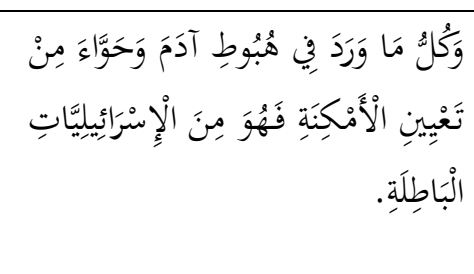 & $\begin{array}{c}\text { Al-Baqarah } \\
37 \\
1: 232\end{array}$ & $\begin{array}{c}\text { Seluruh riwayat } \\
\text { dengan } \\
\text { pembahasan ini } \\
\text { adalah isrāiliyyāt }\end{array}$ & $\begin{array}{c}\text { Mengenai kisah } \\
\text { diturunkannya } \\
\text { Adam ke Bumi }\end{array}$ \\
\hline 4. & 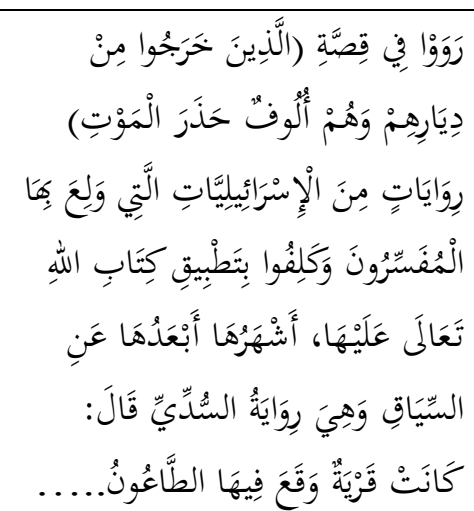 & $\begin{array}{c}\text { Al-Baqarah } \\
263 \\
2: 360\end{array}$ & $\begin{array}{c}\text { Riwayat ini } \\
\text { isrāiliyyāat }\end{array}$ & $\begin{array}{l}\text { Mengenai kisah } \\
\text { orang isrāiliyyāt } \\
\text { yang keluar dari } \\
\quad \text { desanya }\end{array}$ \\
\hline 5. & 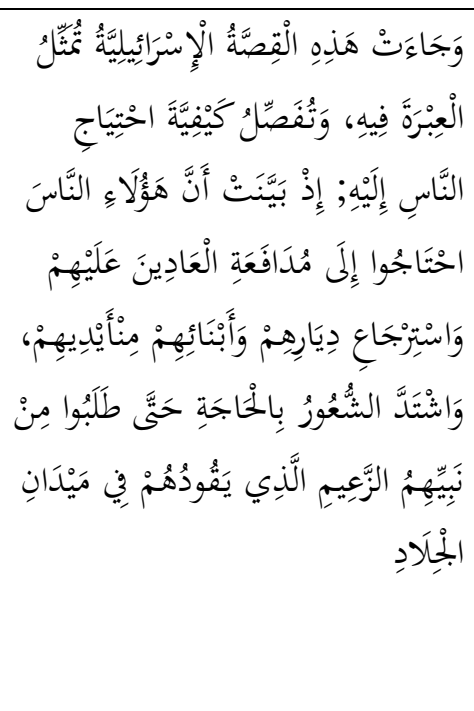 & $\begin{array}{c}\text { Al-Baqarah } \\
246 \\
2: 376\end{array}$ & $\begin{array}{l}\text { Isrāiliyyāt ini } \\
\text { menggambarkan } \\
\text { ibrah dalam ayat } \\
\quad \text { tersebut }\end{array}$ & $\begin{array}{c}\text { Kisah ini } \\
\text { mengenai } \\
\text { kaburnya Bani } \\
\text { isrāiliyyāt dari } \\
\text { kediaman mereka } \\
\text { dan butuhnya } \\
\text { mereka pada Nabi } \\
\text { untuk kembali } \\
\text { merebut hak } \\
\text { mereka }\end{array}$ \\
\hline 6. & 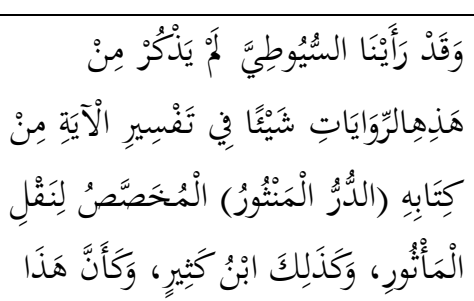 & $\begin{array}{c}\text { Al-Baqarah } \\
19 \\
1: 147\end{array}$ & $\begin{array}{c}\text { Riwayat ini } \\
\text { dianggap } \\
\text { isrāiliyyāt } \\
\text { karena para }\end{array}$ & $\begin{array}{l}\text { Riwayat mengenai } \\
\text { Guntur dan petir }\end{array}$ \\
\hline
\end{tabular}




\begin{tabular}{|c|c|c|c|c|}
\hline \multicolumn{5}{|c|}{$\begin{array}{l}\text { Pandangan Rashīd riḍ̄a terhadap isrāiliyāt dan ..... } \\
\text { Muḥammad Akrom Adabi dan Abdullah Mubarok }\end{array}$} \\
\hline No. & Kutipan & $\begin{array}{c}\text { Surat: } \\
\text { ayat } \\
\text { Juz: hal }\end{array}$ & Status & Tema \\
\hline & 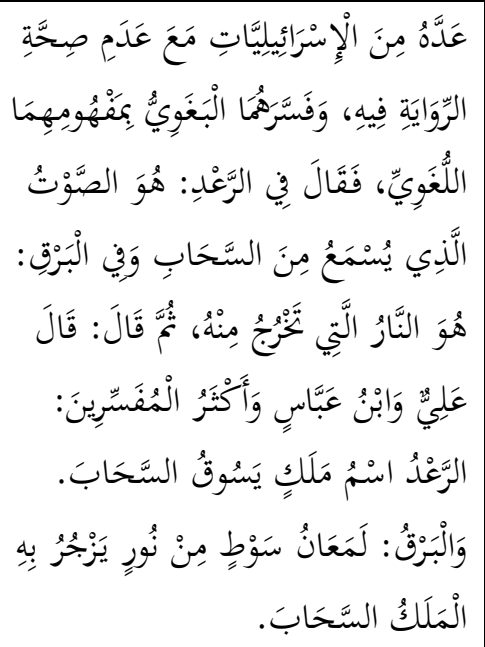 & & $\begin{array}{c}\text { pengutip tidak } \\
\text { menyebutkan } \\
\text { sanad yang valid } \\
\text { yang marfu } \\
\text { sampai kepada } \\
\text { Nabi }\end{array}$ & \\
\hline 7. & 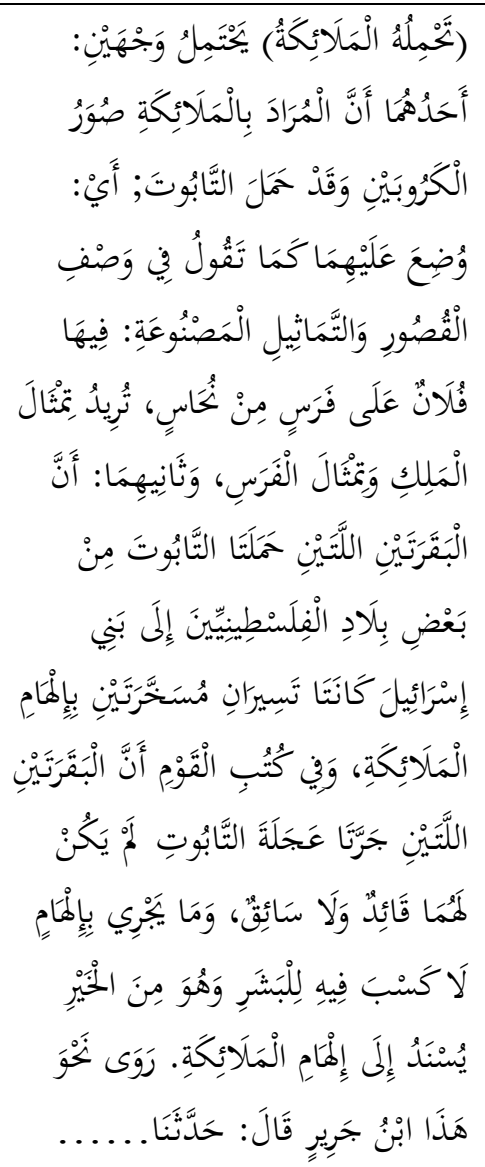 & $\begin{array}{c}\text { Al-Baqarah } \\
\text { 248 } \\
2: 385\end{array}$ & $\begin{array}{c}\text { Mengutip } \\
\text { isrāiliyyātdengan } \\
\text { tanpa mengkritik }\end{array}$ & $\begin{array}{c}\text { Mengenai siapa itu } \\
\text { malaikat yang } \\
\text { membawa pusaka } \\
\text { Tabut }\end{array}$ \\
\hline
\end{tabular}

\section{Analisa Isrāiliyyāt dalam Tafsir al-Manār}

Melalui data diatas, dapat dilihat dimana Rị̣ā mengutip isrāiliyyāt dalam 7 tempat pengutipan 5 diantaranya adalah penegasan Riḍā dalam menjauhi isrāiliyyāt. 


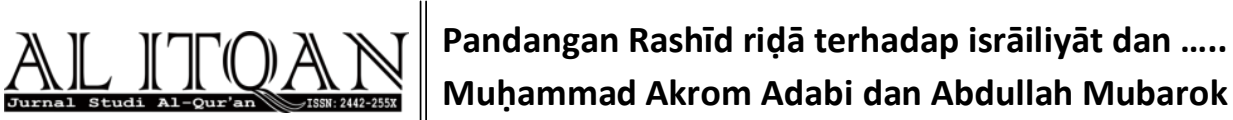

Angka ini terbilang besar dan bersesuaian dengan prinsip yang dibangun oleh Riḍā sendiri, yakni menjauhi isrāiliyyāt.

Kemudian, dua pengutipan Riḍā yang lainnya yakni pada al-Baqarah 246 mengenai kisah eksodus Bani Israil dan ayat 248 mengenai siapa sebenarnya malaikat pembawa pusaka tabut. Pengutipan yang dimaksud adalah pengutipan sebagai penafsiranm dimana Rị̣ā hanya menukilnya tanpa mengoreksi, mengkritisi atau menolaknya seperti kebiasaannya yang lalu.

Untuk surat al-Baqarah ayat 246, Riḍā bahkan menegaskan bahwa kisah isrāiliyyāt yang dikutipnya itu menggambarkan ibrah dari suatu ayat. ${ }^{53}$ Kemudian mengenai al-Baqarah 248, dalam menafsirkan "تحمله الملائكة pada akhir penjelasan Riḍā menyampaikan bahwa informasi ini juga disampaikan oleh Ibnu Jarīr yang diperolehnya dari Wahab bin Munabbih. ${ }^{54}$ Hal ini Riḍa sampaikan tanpa adanya kritikan ataupun koreksi.

Dalam pengamatan penulis, penjelasan tersebut jelas-jelas memiliki esensi sama dengan yang ditolak oleh Riḍā. Penjelasan tersebut tidak terlalu penting bagi pembaca untuk diketahui siapa sebenarnya malaikat pembawa pusaka tabut, seperti apa sejatinya dan siapa sebenarnya mereka. Terlebih dalam ayat ini juga bersumber dari Wahab bin Munabbih yang sebelumnya telah dikritik oleh Rị̣ā.

Pengutipan ini, menurut hemat penulis, tidak bisa menunjukkan persetujuan Riḍā terhadap isrāiliyyāt atau menyetujui isrāiliyyāt dalam hal tertentu. Terlebih ketika data ini dikuatkan dengan fakta penolakan Rị̣ā terhadap isrāiliyyāt yang jika dibandingkan adalah 5 banding 2. Sehingga hal ini menunjukkan ketidak konsistenan Riḍā dalam menolak isrāiliyyāt. Ada beberapa poin yang bisa diambil dari fakta di atas: Pertama, Riḍā tidak konsisten terhadap standar yang dibangunnya sendiri.Isrāiliyyāt yang menurutnya adalah kisah tidak berdasar yang tidak layak untuk ditampilkan, akan tetapi justru ia kutip. Kedua, Riḍā mengkritik para narasumber isrāiliyyāat tapi dalam data di atas Riḍā malah mengutipnya. Ketiga, Riḍā menegaskan salah satu yang tidak disukainya dalam tafsir adalah penjelasan yang menjauhkan pembaca dari ibrah, akan tetapi hal ini dilakukannya sendiri dalam pengutipan tersebut.

\footnotetext{
${ }^{53}$ Ibid., juz 2, hlm. 376.

${ }^{54}$ Ibid., juz 2, hlm. 385.
} 


\section{Pandangan Rashīd riọā terhadap isrāiliyāt dan .....
Muhammad Akrom Adabi dan Abdullah Mubarok}

\section{E. Rashīd Riḍā dan Alkitab}

\section{Alkitab dalam Pandangan Rashīd Riḍā}

Dalam masalah Alkitab, pendapat Riḍā tidak berbeda dengan kebanyakan para ulama yang menyatakan bahwa baik Taurat maupun Injil telah mengalami distorsi. Menurutnya didalamnya terjadi banyak penyimpangan. Untuk memperkuat pendapat ini Riḍā mengutip Shaikh Raḥmatullāh al-Hindi, melalui bukunya yang berjudul Izhār al-Haq, Syekh al-Hindi menyebutkan 100 bukti penyelewengan Alkitab. Penyelewengan tersebut ada yang berupa makna dan ada yang berupa teks. ${ }^{55}$

Rị̣ā juga menyandarkan pendapatnya pada ayat al-Qur'an. Diantaranya adalah surat al-Māidah ayat 14:

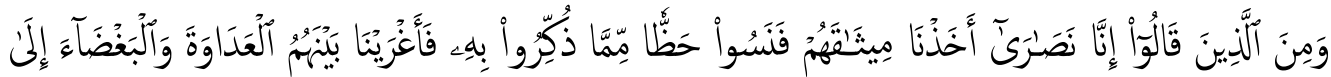

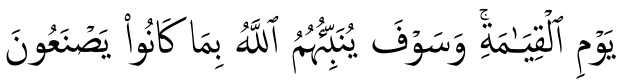

Dan diantara orang-orang yang mengatakan: "Sesungguhnya kami ini orang-orang Nasrani", ada yang telah kami ambil perjanjian mereka, tetapi mereka (sengaja) melupakan sebagian dari apa yang mereka telah diberi peringatan dengannya; maka Kami timbulkan di antara mereka permusuhan dan kebencian sampai hari kiamat. Dan kelak Allah akan memberitakan kepada mereka apa yang mereka kerjakan. (QS. al-Māidah [5]: 14)

Rị̣ā mengatakan bahwa Alkitab tidak mengalami masa transmisi yang sempurna. Ia menyebutkan fakta sejarah dimana Alkitab tidak memiliki sumber periwayatan dan penulisan yang kuat. Baik Yahudi maupun Nasrani menurutnya telah kehilangan kitab suci mereka. Bahkan, kitab orang Nasrani hilang lebih cepat dari pada Yahudi karena tidak adanya dokumentasi di masa awal. Adapun Taurat pada masa diturunkannya pernah ditulis akan tetapi kitab tersebut hilang pada masa setelahnya. $^{56}$

Selain itu Riḍā juga mendasarkan argumennya pada tiga alasan : (1) tidak ada bukti otentik yang menunjukkan bahwa kitab suci mereka itu terjaga dari kesalahan begitu juga dengan para penulisnya. (2) Ketidak-mutawatir-an materi Alkitab menjadi alasan kesalahan utama (3) Informasi yang disampaikan Alkitab terkadang saling bertentangan, seperti yang dijumpai pada Injil Barnabas. ${ }^{57}$

\footnotetext{
${ }^{55}$ Ibid., juz 5, hlm. 114.

${ }^{56}$ Riḍā, Tafsir al-Manār, juz 3, hlm. 131.

${ }^{57}$ Ibid., juz 6, hlm. 29.
} 


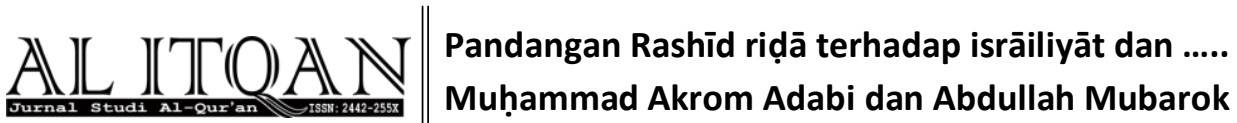

Alkitab dalam pandangan Rị̣ā adalah sebuah kitab suci yang berisi Injil dan Taurat yang masih diyakini kebenaranya oleh Ahli Kitab itu sendiri. Riḍā meyakini bahwa Alkitab sudah tidak otentik lagi.Terjadi banyak penyelewengan, penambahan dan pengurangan di dalamnya.

Akan tetapi, dalam bukunya Riḍā menggunakan Alkitab sebagai sumber penafsiran. Hal ini olehnyadianggap sebagai pengutipan yang masih wajar karena pengutipannya tidak pada batas membenarkan atau menyalahkan tapi dalam batas menangguhkan. Rị̣ā berkata dalam kitabnya :

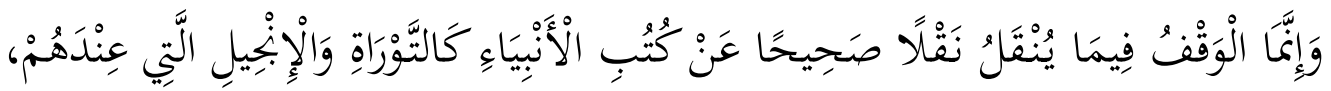

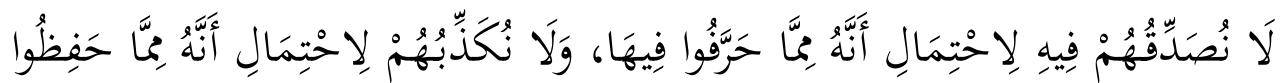

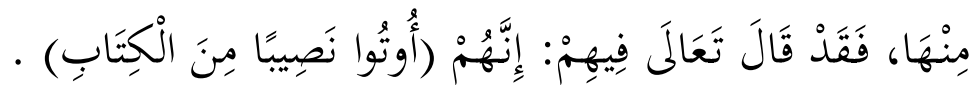

Penangguhan riwayat șaḥịh yang berasal dari kitab-kitab para nabi seperti Taurat dan Injil adalah dengan tidak membenarkannya,karena masih ada kesamaran, bisa jadi itu bagian dari yang mereka rubah. Juga tidak pula dengan menganggapnya palsu karena bisa jadi itu bagian dari yang masih otentik yang mereka jaga. ${ }^{58}$

\section{Implementasi Pengutipan Alkitab}

Sebagaimana penjelasan sebelumnya bahwa Rashīd Rị̣ā mengakui bahwa Alkitab telah mengalami penyimpangan dan tidak otentik lagi.Akan tetapi dalam bukunya Rị̣ā banyak sekali mengutip Alkitab.Untuk menelusuri hal ini, dilakukan penelusuran data dalam surat al-Baqarah. Hasilnya ditemukan 19 kali pengutipan Alkitab oleh Riḍā dalam Tafsiral-Manār. Berikut rekapan temuan tersebut:

\begin{tabular}{|c|c|c|c|}
\hline No. & Kutipan & Sumber & $\begin{array}{c}\text { Surat: ayat } \\
\text { Juz: hal }\end{array}$ \\
\hline 1. & 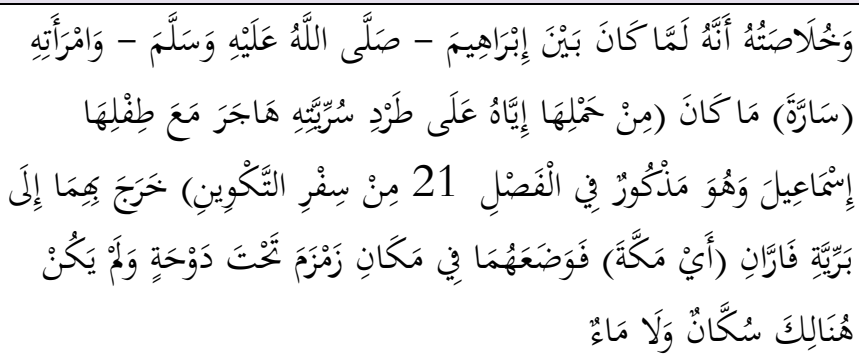 & $\begin{array}{c}\text { Kitab } \\
\text { Kejadian }\end{array}$ & $\begin{array}{c}\text { Al-Baqarah } \\
158 \\
2: 37\end{array}$ \\
\hline 2. & 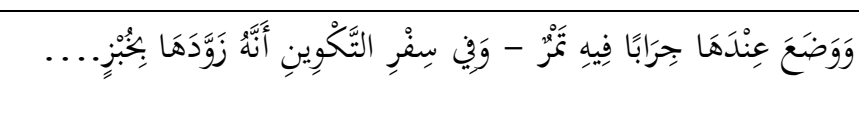 & $\begin{array}{c}\text { Kitab } \\
\text { Kejadian }\end{array}$ & $\begin{array}{c}\text { Al-Baqarah } \\
158\end{array}$ \\
\hline
\end{tabular}

\footnotetext{
${ }^{58}$ Ibid., juz 1, hlm. 10.
} 


\begin{tabular}{|c|c|c|c|}
\hline \multicolumn{2}{|r|}{$\begin{array}{l}\text { Pandangan Rashīd riḍā terhadap isrāiliyāt dan ..... } \\
\text { Muḥammad Akrom Adabi dan Abdullah Mubarok }\end{array}$} & AlL & \\
\hline No. & Kutipan & Sumber & $\begin{array}{l}\text { Surat: ayat } \\
\text { Juz: hal }\end{array}$ \\
\hline & & & $2: 37$ \\
\hline 3. & 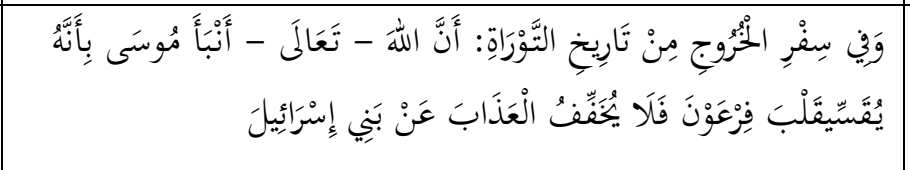 & $\begin{array}{c}\text { Kitab } \\
\text { Keluaran }\end{array}$ & $\begin{array}{l}\text { Al-Baqarah } \\
53 \\
1: 260\end{array}$ \\
\hline 4. & 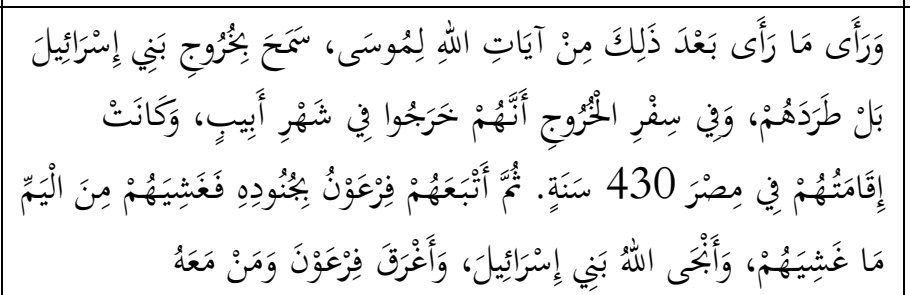 & $\begin{array}{c}\text { Kitab } \\
\text { Keluaran }\end{array}$ & $\begin{array}{c}\text { Al-Baqarah } \\
53 \\
1: 261\end{array}$ \\
\hline 5. & 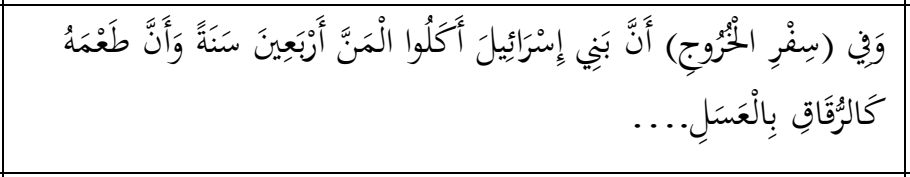 & $\begin{array}{c}\text { Kitab } \\
\text { Keluaran }\end{array}$ & $\begin{array}{c}\text { Al-Baqarah } \\
57 \\
1: 268 \\
\end{array}$ \\
\hline 6. & 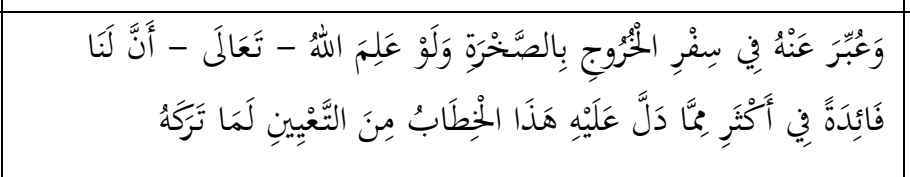 & $\begin{array}{c}\text { Kitab } \\
\text { Keluaran }\end{array}$ & $\begin{array}{l}\text { Al-Baqarah } \\
60 \\
1: 271\end{array}$ \\
\hline 7. & 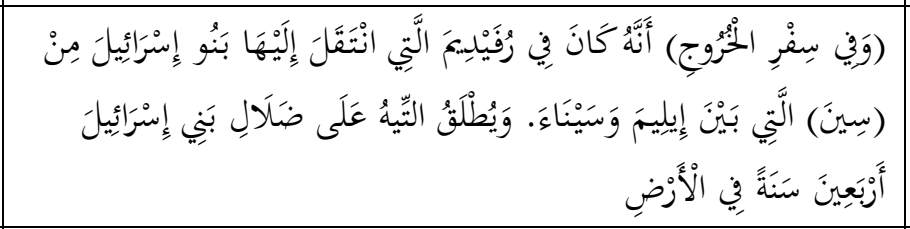 & $\begin{array}{c}\text { Kitab } \\
\text { Keluaran }\end{array}$ & $\begin{array}{l}\text { Al-Baqarah } \\
\quad 60 \\
1: 272\end{array}$ \\
\hline 8. & 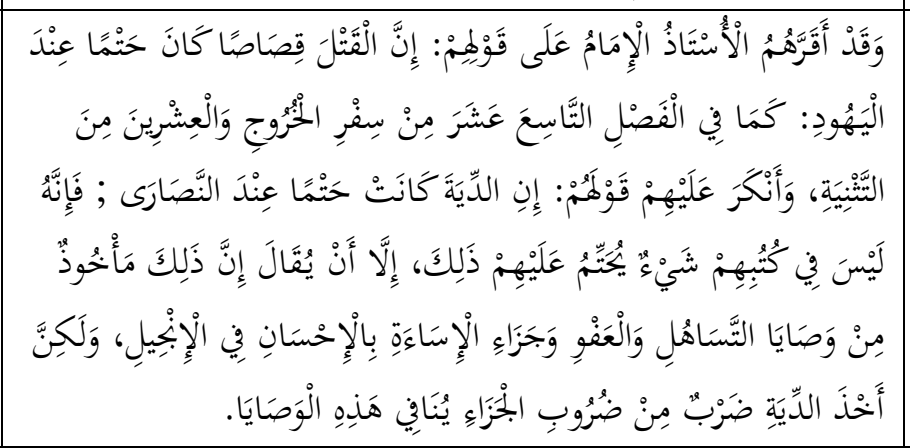 & $\begin{array}{c}\text { Kitab } \\
\text { Keluaran }\end{array}$ & $\begin{array}{c}\text { Al-Baqarah } \\
177 \\
2: 99\end{array}$ \\
\hline 9. & 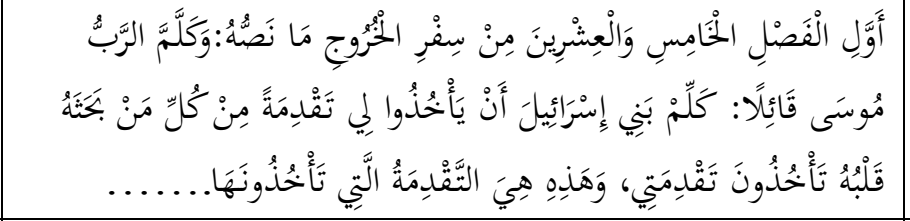 & $\begin{array}{c}\text { Kitab } \\
\text { Keluaran }\end{array}$ & $\begin{array}{l}\text { Al-Baqarah } \\
248 \\
2: 382\end{array}$ \\
\hline 10. & 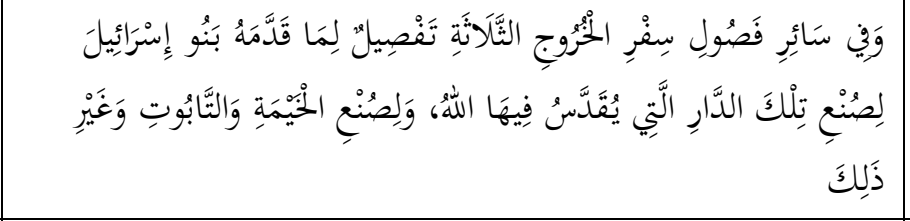 & $\begin{array}{c}\text { Kitab } \\
\text { Keluaran }\end{array}$ & $\begin{array}{l}\text { Al-Baqarah } \\
248 \\
2: 384\end{array}$ \\
\hline 11. & 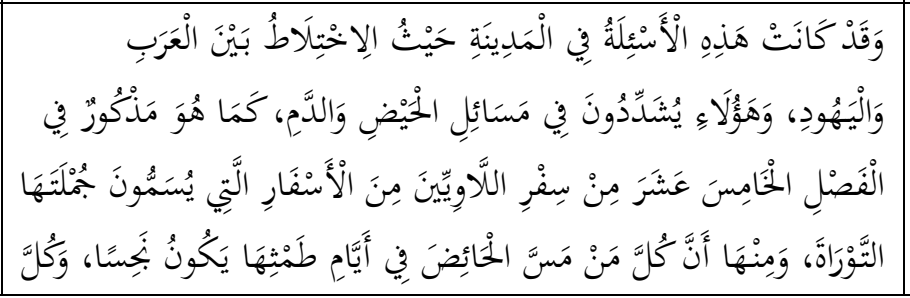 & $\begin{array}{l}\text { Kitab } \\
\text { Lewi }\end{array}$ & $\begin{array}{l}\text { Al-Baqarah } \\
222 \\
2: 285\end{array}$ \\
\hline
\end{tabular}




\begin{tabular}{|c|c|c|c|}
\hline No. & Kutipan & Sumber & $\begin{array}{l}\text { at: ayat } \\
\text { lz: hal }\end{array}$ \\
\hline & 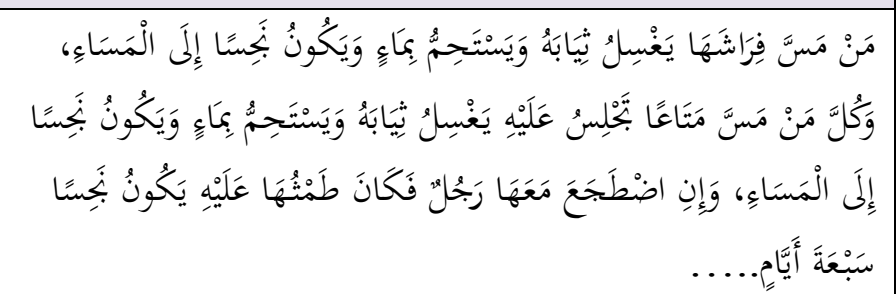 & & \\
\hline 12. & 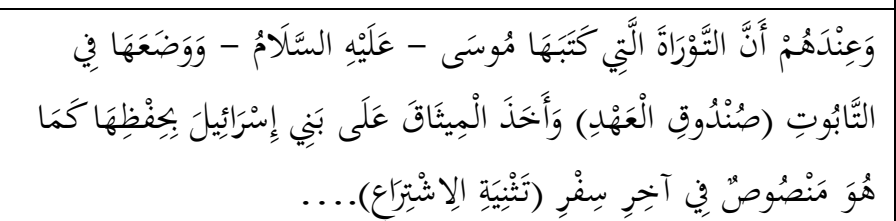 & $\begin{array}{c}\text { Kitab } \\
\text { Ulangan }\end{array}$ & $\begin{array}{c}\text { Al-Baqarah } \\
24 \\
1: 174\end{array}$ \\
\hline 13. & 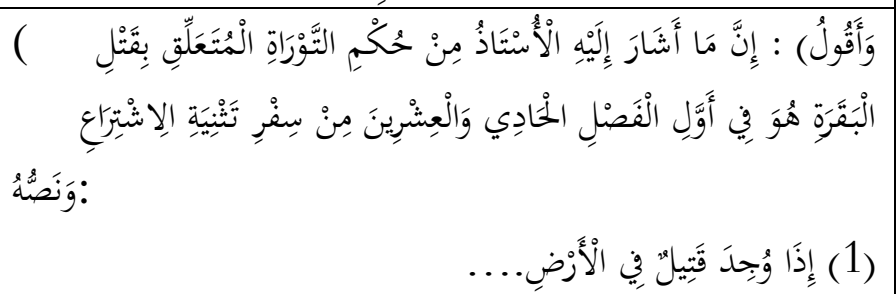 & $\begin{array}{c}\text { Kitab } \\
\text { Ulangan }\end{array}$ & $\begin{array}{l}\text { Al-Baqarah } \\
72 \\
1: 288\end{array}$ \\
\hline 14. & 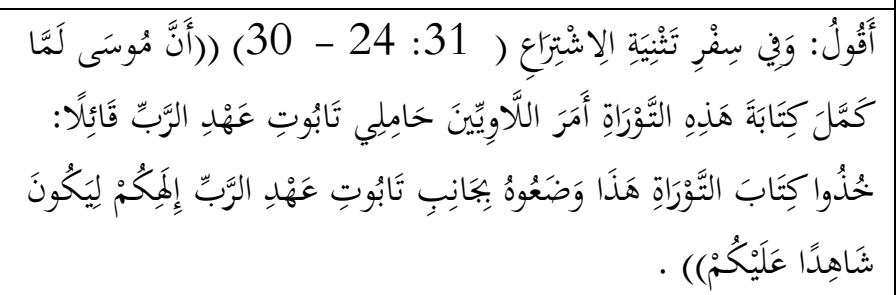 & $\begin{array}{c}\text { Kitab } \\
\text { Ulangan }\end{array}$ & $\begin{array}{c}\text { Al-Baqarah } \\
248 \\
2: 384\end{array}$ \\
\hline 15. & 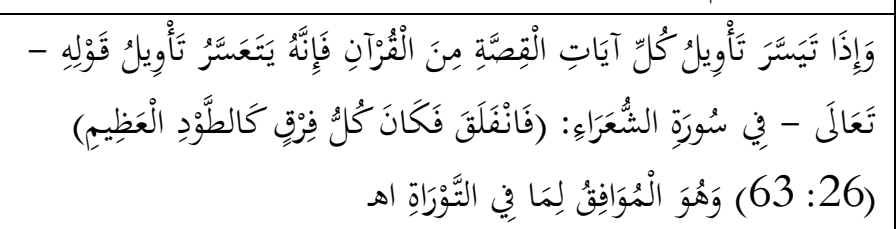 & & $\begin{array}{c}\text { Al-Baqarah } \\
50 \\
1: 262\end{array}$ \\
\hline 16. & 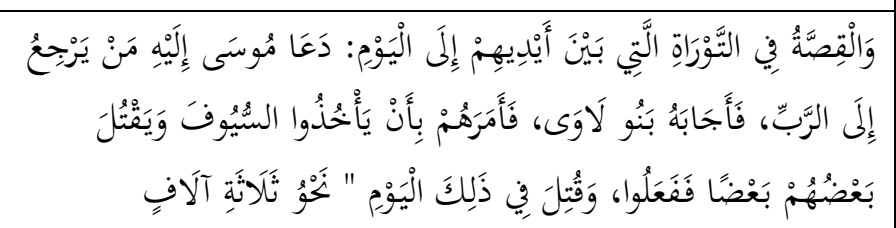 & & $\begin{array}{c}\text { Al-Baqarah } \\
54 \\
1: 266\end{array}$ \\
\hline 17. & 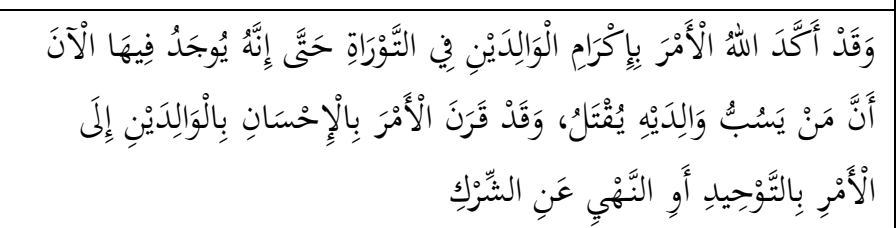 & Taurat & $\begin{array}{l}\text { Al-Baqarah } \\
\quad 83 \\
1: 303\end{array}$ \\
\hline 18. & 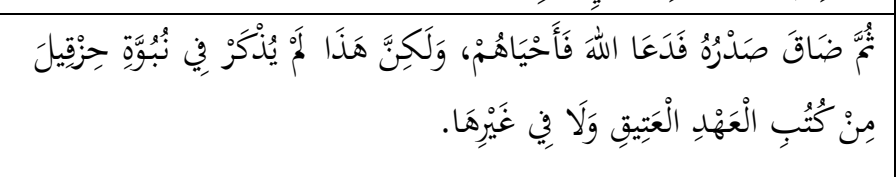 & $\begin{array}{l}\text { Perjanjian } \\
\text { Lama }\end{array}$ & $\begin{array}{l}\text { Al-Baqarah } \\
243 \\
2: 361\end{array}$ \\
\hline 19. & 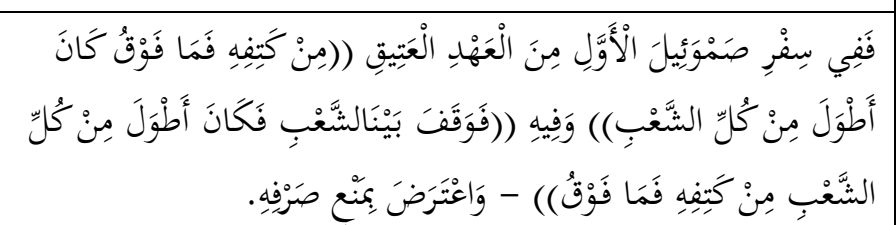 & $\begin{array}{c}\text { Perjanjian } \\
\text { Lama }\end{array}$ & $\begin{array}{c}\text { Al-Baqarah } \\
247 \\
2: 378\end{array}$ \\
\hline
\end{tabular}




\section{Pandangan Rashīd riọ̄ā terhadap isrāiliyāt dan .....
Muhammad Akrom Adabi dan Abdullah Mubarok}

\section{Analisa Pandangan Riḍā terhadap Alkitab dan Implementasinya}

Sebagaimana keterangan di muka,Riḍa menjelaskan bahwa pengutipannya pada Alkitab adalah sebagai sumber yang tidak diyakini kebenarannya, penukilannya masih berada pada tataran penangguhan kebenaran Alkitab itu sendiri. Sebab Riḍā secara pribadi meyakini bahwa di dalam Alkitab memang terdapat pengkaburan antara yang masih murni dan yang sudah berubah dari kitab asli.

Akan tetapi jika ditelaah lebih lanjut, akan terlihat di mana Riḍā memberi posisi lebih terhadap Alkitab.Rị̣ā seolah menempatkan Alkitab sebagai standar kebenaran riwayat.Hal ini bisa dilihat dalam beberapa contoh di atas seperti saat Riḍā menjabarkan panjang lebar kisah eksodus Bani Israel dengan mengutip dari Alkitab yang kemudian ia jelaskan.

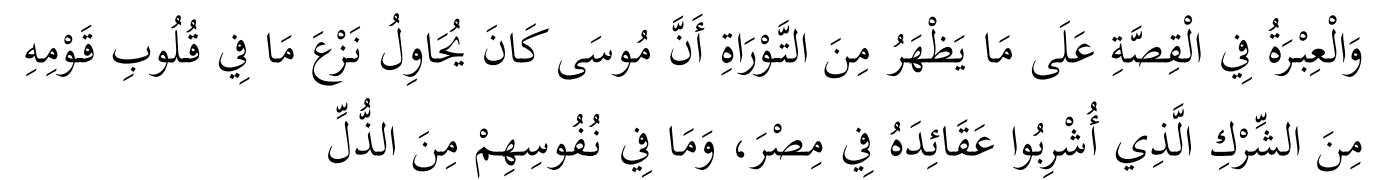

Pelajaran dalam kisah yang ada di Taurat adalah bahwa Musa mengubah kesyirikan yang ada di hati kaumnya yang disebabkan oleh pengaruh aqidah di Mesir.Musa juga mengubah kehinaan yang ada dalam jiwa mereka. ${ }^{59}$

Hal serupa juga bisa dilihat dalam kasus pembunuhan sapi. Rị̣ā begitu bersemangat merendahkan kisah-kisah para mufassir bahwa dirinya tidak menerima kecuali riwayat yang șaḥị̣. Akan tetapi setelah itu ia menegaskan bahwa penjelasan serupa (mengenai kasus pembunuhan dan sapi) juga ditemukan dalam kitab Kejadian di Taurat.

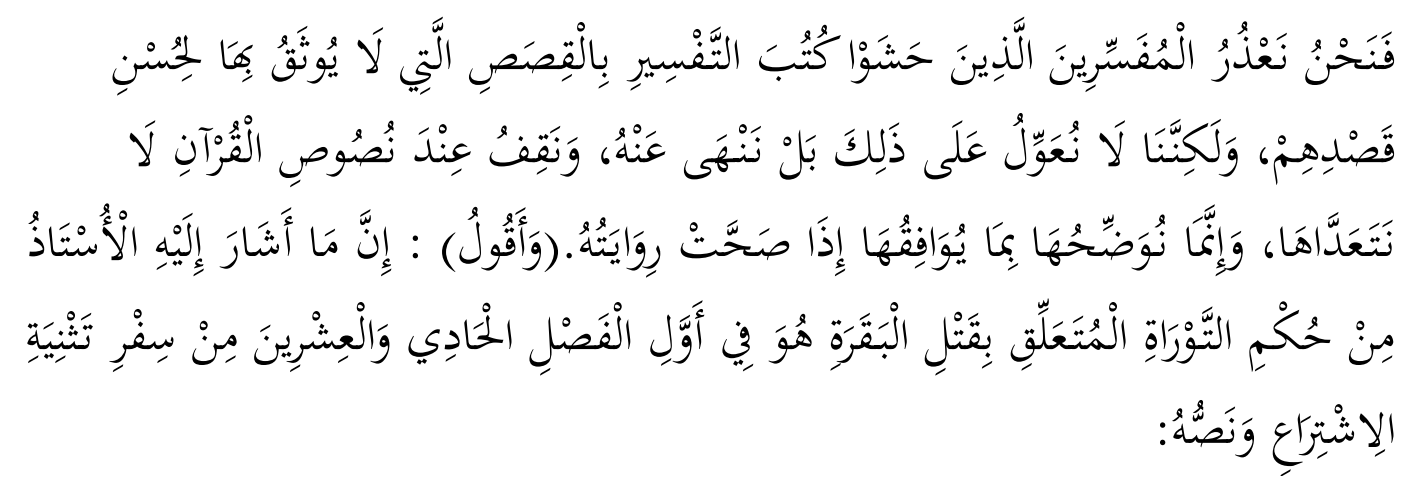

Kami masih bisa mentolerir para mufassir yang mencampurkan tafsir dengan kisah-kisah yang tidak kuat karena tujuan baik mereka. Akan tetapi kami tidak menjadikan kisah tersebut sebagai pegangan bahkan kami menolaknya. Kami hanya berpegang pada nas Alquran tanpa menentang. Dan kami akan

\footnotetext{
${ }^{59}$ Ibid., juz 1, hlm. 272.
} 


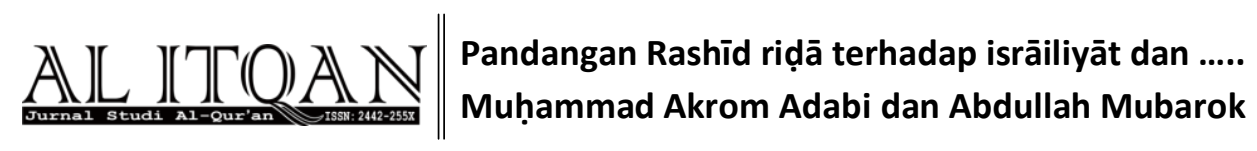

menjelaskan al-Qur'an dengan riwayat yang sesuai jika memang riwayatnya șahīh. Bahwa yang diisyaratkan ustad (Muhammad Abduh) mengenai hukum Taurat yang berhubungan dengan pembunuhan sapi ini ada di ayat pertama pasal 11 kitab Ulangan berikut redaksinya. ${ }^{60}$

Dalam kesempatan lain diluar surat al-Baqarah juga ditemukan keterangan Riḍā yang menampakan bagaimana ia memberi posisi lebih pada Alkitab. Riḍā berkata:

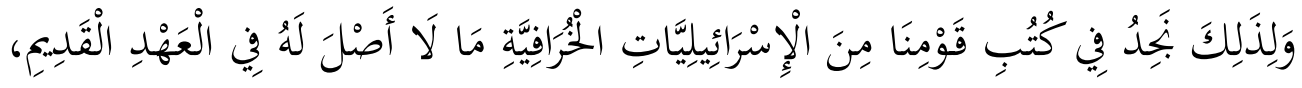

Oleh sebab itulah (susupan orang-orang Yahudi), dalam buku tafsir kita banyak menemukan khurafat isräiliyyātyang tidak ada dasarnya sama sekali dalam Perjanjian Lama. ${ }^{61}$

Pada bagian ini jelas Rị̣ā mencoba mengkritik isrāiliyyāt yang banyak ditemuinya dalam buku buku tafsir asik akan tetapi Rị̣ā memberi sebuah perbandingan yang seolah perbandingan tersebut Seharusnya yang menjadi rujukan utama.

\section{F. Esensi Perbedaan Isrāiliyyāt dan Alkitab}

Isrāiliyyāt maupun Alkitab keduanya memiliki esensi yang sama. Alkitab pada dasarnya adalah rujukan isrāīliyyātt itu sendiri. Akan tetapi ada perbedaan epistemologi yang membedakan keduanya. Selain itu, dalam perkembangannya isrāiliyyāt memiliki pengertian yang lebih luas. Dalam hal ini, Riḍā memberi sikap yang berbeda pada isrāiliyyāt dan Alkitab. Rị̣ā secara tegas tidak menyetujui masuknya isrāiliyyāt dalam penafsiran tetapi dibalik penolakannya itu Riḍā banyak mengutip Alkitab.

Sejauh pengamatan penulis ada berbagai pandangan yang disampaikan Riḍā yang bisa menggambarkan bagaimana esensi perbedaan antara Alkitab dan isrāiliyyāt. Secara sederhana, logika Riḍā bisa digambarkan dengan bagaimana mungkin seseorang merujuk kepada sumber Ahli Kitab sedangkan sumber itu sendiri tiada mereka tahu dan tiada mereka sepakati. Maka Alkitab dengan berbagai polemiknya tetaplah Alkitab yang menjadi sumber rujukan dan menjadi pegangan oleh Ahli Kitab itu sendiri. Dalam bukunya Riḍā menyampaikan.

\footnotetext{
${ }^{60}$ Ibid., juz 1, hlm. 288.

${ }^{61}$ Ibid., juz 4, hlm. 219.
} 


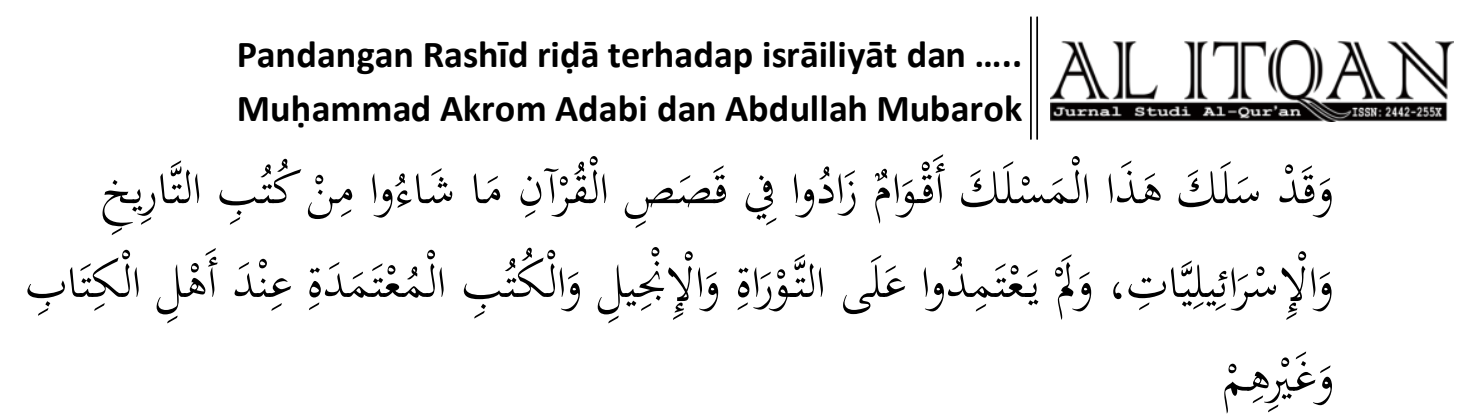

Dan beberapa orang telah menggunakan hal ini (penukilan isräiliyyāt). Mereka menambahkan kisah-kisah semaunya sendiri dari buku-buku isrāiliyyāt tanpa berpegang pada Taurat, Injil dan buku-buku pegangan Ahli Kitab yang lainnya. ${ }^{62}$

Dalam kesempatan lain juga ditemukan penjelasan serupa. Menurut Riḍā, penting bagi kita untuk merujuk kepada sumber yang disepakati oleh pemiliknya itu sendiri. Maka, dalam masalah kisah, untuk menggunakannya sebagai tafsir pun harus merujuk kepada Alkitab yang memang disepakati oleh Ahli Kitab itu sendiri.

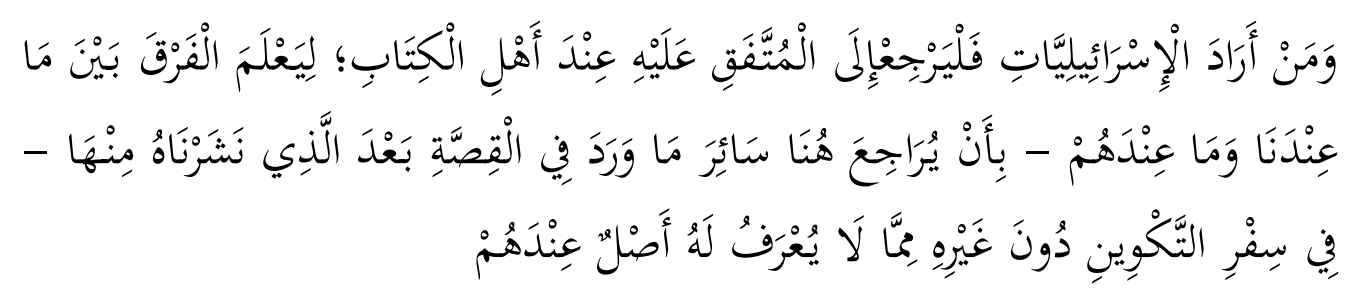

Barangsiapa yang ingin mengambil isräiliyyāt. Maka hendaklah ia merujuk pada kitab yang disepakati oleh Ahli Kitab agar diketahui sisi perbedaan dari apa yang ada di antara kita dan mereka. Caranya adalah dengan merujuk pada seluruh kisah yang dikupas pada (salah satunya) kitab kejadian. Bukan referensi lain yang tidak diketahui asal usulnya. ${ }^{63}$

Melalui pengertian tentang isrāiliyyāt dan Alkitab yang digambarkan oleh Riḍā, serta Letak perbedaan yang telah dijelaskan di atas, maka dapat digambarkan letak perbedaan isrāiliyyāt dan Alkitab dalam pandangan Riḍā sebagai beriku.

1. Sumber dalam Alkitab merupakan murni Alkitab yang ada di tangan pemilik kitab suci tersebut, berbeda dengan isrāiliyyāt yang terjadi ketidakjelasan di dalamnya.

2. Alkitab adalah kitab suci yang disepakati dan dibuat pegangan oleh Ahli Kitab itu sendiri, hal ini berbeda dengan isrāiliyyāt.

3. Alkitab memiliki eksistensi yang masih bisa dipertanggungjawabkan menurut Ahli Kitab itu sendiri, hal ini berbeda dengan isrāiliyyāt.

\footnotetext{
${ }^{62}$ Ibid., juz 1, hlm. 17.

${ }^{63}$ Ibid., juz 8, hlm. 316.
} 


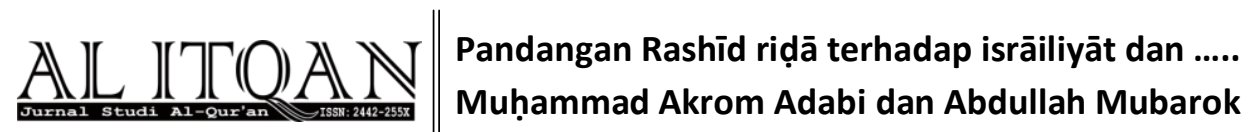

4. Alkitab mulanya merupakan kitab suci yang dibuat pegangan sebagai petunjuk umat manusia meski kemudian terdapat berbagai penyelewengan, tetapi tidak ada motif buruk terhadap Islam, hal ini berbeda dengan isrāiliyyāt.

\section{G. Kesimpulan}

Dalam pandangan Rị̣ā, isrāiliyyāt merupakan kisah-kisah palsu yang diselundupkan oleh Yahudi. Kisah-kisah ini banyak mengandung khurafat dan hal-hal yang tidak masuk akal. Pengutipannya akan menjebak pembaca, untuk tidak memperolehibrah dari suatu ayat. Dalam hal ini, langkah yang diambil Riḍa adalah menjauhi pengutipan isrāiliyyāt sekalipun sumbernya adalah ulama klasik yang diyakini beritanya didapatkan dari nabi. Hal ini menurutnya adalah sebagai upaya pemurnian al-Qur'an.

Penolakan Riḍā terhadap isrāiliyyāt disebabkan oleh 3 hal, Pertama, posisi isrāiliyyāt dalam penafsiran. Bagi Rị̣ā, isrāiliyyāt tidak layak dijadikan sebagai sumber untuk menafsirkan kalam Allah yang agung dan sakral. Kedua, motif di balik isrāiliyyāt, isrāiliyyāt menurutnya perlu diwaspadai karena dijadikan senjata oleh musuh Islam untuk merusak akidah umat. Ketiga, status narasumber isrāiliyyātmenurut Riḍā banyak sekali melakukan penyelewengan dan tidak bisa dijadikan rujukan dalam sumber berita utamanya tafsir.

Rị̣ā sangat selektif dalam memilih sebuah riwayat terutama yang terindikasi isrāiliyyāt. Untuk masalah ini, Rị̣ā tidak segan-segan mengkritik hadis jika isinya memang diindikasi ada susupan isrāiliyyāt. Bagi Rị̣ā hadis Sahabat yang pada tataran tertentu bernilai marfü' pada bagian lā majāla fìhi lil ijtihād perlu dikoreksi lagi. Pasalnya tidak menutup kemungkinan mereka mendapatkan sumber dari Yahudi yang memiliki motif terselubung.

Dalam surat al-Baqarah ada 7 temuan mengenai isrāiliyyāt. Limadiantaranya adalah penegasan Riḍā untuk menolak isrāiliyyāt, dua ayat lain menjadi temuan unik karena ternyata Rị̣ā mengutip isrāiliyyāt tanpa mengkritik atau menolaknya. Data ini menegaskan beberapa hal: Pertama, Riḍā terjebak oleh pengertian yang dibangunnya sendiri. Rị̣ā tidak menyetujui isrāiliyyāt tetapi malah mengutipnya dalam beberapa kesempatan. Kedua narasumber yang menurut Riḍā tertolak pada akhirnya juga turut dikutipnya sendiri. Ketiga, Riḍā juga ikut menafsirkan Al-Qur'an dengan penafsiran yang bisa menjauhkan pembaca dari ibrah utama suatu ayat.

Adapun pandangan Riḍā terhadap Alkitab, ia meyakini bahwa Alkitab sudah tidak lagi otentik. Alkitab tidak mengalami transmisi yang sempurna. Akan tetapi, Rị̣ā tetap menggunakan Alkitab sebagai sumber penafsiran. Hal ini oleh Rị̣ā dianggap sebagai 


\section{Pandangan Rashīd riọ̄ā terhadap isrāiliyāt dan .....
Muhammad Akrom Adabi dan Abdullah Mubarok}

pengutipan yang masih wajar karena pengutipannya terhadap Alkitab tidak pada batas membenarkan ataupun menyalahkan.

Dalam surat Al-Baqarah ditemukan 19 kali pengutipan Alkitab. Melalui pengutipanpengutipan ini ditemukan fakta bahwa, dalam beberapa kesempatan Rị̣ā memberikan porsi berlebih terhadap Alkitab. Riḍa menjadikan Alkitab sebagai sumber rujukan utama. Hal ini jelas bertentangan dengan prinsip yang ia bangun.

Sebenarnya bagi Riḍā sendiri prinsip yang digunakan adalah pengutipan diperbolehkan pada hadis yang memang șạ̣ị̣ marfū' dari Nabi Muhammad. Kalaupun harus terpaksa mengutip dari Yahudi atau Nashrani maka hal tersebut diperkenankan hanya dengan mengutip dari Alkitab. Bagi Riḍā, ada beberapa perbedaan mendasar kenapa hal ini dibenarkan. Pertama, Alkitab sumbernya masih murni Alkitab yang ada di tangan Ahli Kitab, berbeda dengan isrāiliyyāt. Kedua, Alkitab adalah kitab yang disepakati dan dijadikan pegangan oleh ahli kitab itu sendiri, berbeda dengan isrāiliyyāt. Ketiga,Alkitab memiliki eksistensi yang bisa dipertanggungjawabkan menurut Ahli kitab, berbeda dengan isrāiliyyāt. Keempat, Alkitab tidak memiliki indikasi motif buruk terhadap Islam, berbeda dengan isrāiliyyāt.

\section{DAFTAR PUSTAKA}

Arsip catatan hasil Muktamar Islam Internasional mengenai "Metode Pakar Tafsir dan Penyarah Hadis" tahun 2006 di International Islamic University Malaysia.

Arslan, Amīr Shakīb.al-Sayyid Rashīd Riḍā. Kairo : Dār al-Fadhīlah, tt.

Al-Dhahaby, Husain. al-Tafsīr wa al-Mufassirūn.tk: Mus'ab Ibn 'Umayr al-Islāmiyah, 2004. Isrāiliyyāt fì Tafsīr wa al-Hadìth. Kairo : Maktabah Wahbah, t.th.

Keene, Michael.Alkitab, Sejarah, Proses dan Pengaruhnya, Terj. Y Dwi Koratno. Yogyakarta: Kanisius, 2006.

Marāghī (al),Mușțafā. Tafsīr al-Marāghī. Mesir : Shirkah Maktabah Muṣtafā al-Bābī al-Ḥablī wa Awlāduh. $1365 \mathrm{H}$.

Mutawallī, Tāmir.Manhaj Rashīd Riḍā fì al- 'Aqīdah. Jedah : Dār al-Majīd al-'Usayri, 2004.

Riḍā, Rashīd.Tafsir al-Manār. Mesir : Hay’ah al-Miṣriyah, 1990.

Rūmy (al), Fahd.Manhaj al-Madrasah al-'Aqliyah al-Hadithah fì al-Tafsīr. Riyadh : Muassasah al-Risalah, 1983.

Sahin, Emad Eldin.Modernisasi Bukan Westernisasi, terj. M. Hefni. Yogyakarta : Madani Pustaka Hikmah, 2002. 


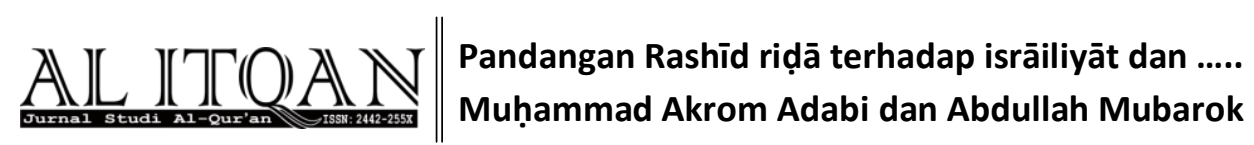

Șibāgh (al), Muhammad. Lamahật fì Ulūm al-Qur'ān Wa Ittijāhāt al-Tafsīr. Beirut : alMaktab al-Islāmī, 1990.

Sugono, Dendy dkk.Kamus Besar Bahasa Indonesia. Jakarta: Pusat Bahasa, 2008.

Usman. "Memahami Israiliyat dalam Penafsiran al-Qur'an", dalam Jurnal Ulumuna, Vol. 5, No. 2. 